\title{
Holocene phototrophic community and anoxia dynamics in meromictic Lake Jaczno (NE Poland) using high-resolution hyperspectral imaging and HPLC data
}

\author{
Stamatina Makri ${ }^{1,2}$, Andrea Lami ${ }^{3}$, Luyao Tu${ }^{1,2}$, Wojciech Tylmann ${ }^{4}$, Hendrik Vogel ${ }^{2,5}$, and Martin Grosjean ${ }^{1,2}$ \\ ${ }^{1}$ Institute of Geography, University of Bern, Hallerstrasse 12, 3012 Bern, Switzerland \\ ${ }^{2}$ Oeschger Centre for Climate Change Research, University of Bern, Hochschulstrasse 4, 3012 Bern, Switzerland \\ ${ }^{3}$ ISE-CNR Institute of Ecosystem Study, 50 Largo Tonolli, 28922 Verbania Pallanza, Italy \\ ${ }^{4}$ Faculty of Oceanography and Geography, University of Gdańsk, Bazynskiego 4, 80952 Gdańsk, Poland \\ ${ }^{5}$ Institute of Geological Sciences, University of Bern, Baltzerstrasse 1+3, 3012 Bern, Switzerland
}

Correspondence: Stamatina Makri (stamatina.makri@giub.unibe.ch)

Received: 30 September 2020 - Discussion started: 22 October 2020

Revised: 29 December 2020 - Accepted: 30 December 2020 - Published: 17 March 2021

\begin{abstract}
Global spread of hypoxia and less frequent mixing in lakes is a major growing environmental concern. Climate change and human impact are expected to increasingly deteriorate aquatic ecosystems. The study of processes and drivers of such changes in the past provides a great asset for prevention and remediation in the future. We used a multiproxy approach combining high-resolution bulk pigment data measured by hyperspectral imaging (HSI) with lowerresolution specific chlorophyll types and carotenoids measured by HPLC to examine Holocene trophic state changes and anoxia evolution in the meromictic Lake Jaczno, NE Poland. A redundancy analysis (RDA) including polleninferred vegetation cover, temperature and human impacts provides insight into specific conditions and drivers of changing trophic and redox states in the lake. Anoxic and sulfidic conditions were established in Lake Jaczno after initial basin infilling 9500 years ago. Until $6700 \mathrm{cal} \mathrm{BP}$, lake trophy was relatively low, water turbidity was high and green sulfur bacteria (GSB) were abundant within the phototrophic community, suggesting a deep oxic-anoxic boundary and weak stratification. The period between $6700-500 \mathrm{cal} \mathrm{BP}$ is characterized by constantly increasing lake production and a gradual shift from GSB to purple sulfur bacteria (PSB), suggesting a shallower oxic-anoxic boundary and pronounced stratification. Yet, the presence of spheroidene and speroidenone in the sediments indicates intermittent anoxia. After $500 \mathrm{cal} \mathrm{BP}$, increasing human impact, deforestation and in-
\end{abstract}

tensive agriculture promoted lake eutrophication, with a shift to PSB dominance and establishment of permanent anoxia and meromixis. Our study unambiguously documents the legacy of human impact on processes determining eutrophication and anoxia.

\section{Introduction}

Eutrophication and subsequent oxygen depletion have become primary water quality issues for most freshwater and coastal marine ecosystems globally (Schindler, 2006; Jenny et al., 2016a). Rising mean global temperature can potentially worsen lake anoxia by enhancing water stratification and algal blooms (Adrian et al., 2009; Woolway and Merchant, 2019). Higher lake trophy and reducing conditions in anoxic bottom waters can have diverse and profound negative effects on lake ecosystems, such as toxic algal blooms, fish kills, biodiversity loss (Smol, 2010; Battarbee and Bennion, 2012; Makri et al., 2019), and nutrient recycling into the water column from the sediment through redox processes (Gächter, 1987; Tu et al., 2019). Hence, the global spread of hypoxia is growing into a major environmental concern (Diaz and Rosenberg, 2008). 
Temporal and spatial extents of hypoxia and anoxia are influenced by both biological (aquatic production, organic matter decomposition) and physical (water stratification and lake mixing) factors (Smith and Schindler, 2009; Friedrich et al., 2014; Jenny et al., 2016b). Environmental and climatic effects such as temperature, seasonality and extreme events, catchment vegetation, land use, human impact, and nutrient input affect lake production and oxygen supply in the bottom waters.

Observational data of anoxia and aquatic production usually cover only very short periods, which restricts the understanding of relevant processes and the knowledge of predisturbance conditions. This is most relevant for lake management or restoration. Although recent anoxia and eutrophication have been very well studied and understood (Naeher et al., 2013; Friedrich et al., 2014; Jenny et al., 2016a), less is known about the onset, cessation and specific conditions of these changes in the past due to the lack of effective and easily measurable proxies (Friedrich et al., 2014; Makri et al., 2020). More specifically, to assess lake trophy and/or bottom-water oxygenation, proxies such as sedimentary pigments (Lami et al., 2000; Leavitt and Hodgson, 2001; Guilizzoni and Lami, 2002); lipid biomarkers (Naeher et al., 2012); diatom (Bennion and Simpson, 2011) and chironomid (Little et al., 2000) records; stable isotopes (Pearson and Coplen, 1978); and redox-sensitive elements such as Fe, Mn, Mo, V and U (Naeher et al., 2013; Wirth et al., 2013; Costa et al., 2015) have been extensively used so far. Nonetheless, on long-term Holocene timescales, most of these proxy records are typically established at a centennial resolution at best.

Laminated lake sediments are valuable archives of natural and anthropogenic impacts, providing long-term records via various biogeochemical proxies. Sedimentary photosynthetic pigment records can be effectively used to infer changes in both algal composition and lake oxygen conditions (Guilizzoni et al., 1983; Leavitt, 1993; Lami et al., 2000). Chlorophyll types, together with their derivatives, and various carotenoids specific to particular groups of algae can be used to reconstruct overall primary production and the composition of past photosynthetic communities (Leavitt and Hodgson, 2001). Pigments such as okenone and isorenieratene, which are specific to phototrophic sulfur bacteria that live in the anoxic sulfidic zones, are regarded as very good indicators of anoxia (Züllig, 1989; Guilizzoni and Lami, 2002). HPLC-inferred pigments have a coarser temporal resolution due to laborious sample preparation and time-consuming HPLC measurements. Scanning hyperspectral imaging (HSI), a novel non-destructive method to quantitatively infer the abundance of algal ( $T \mathrm{Chl}$ is chlorophyll $a$ and $b$, and their derivatives) and bacterial (Bphe is bacteriopheophytin $a$ and $b$ ) pigments, offers insight into past trophic and oxygen conditions at an unprecedented micrometer-scale (sub-seasonal) resolution (Butz et al., 2015; Makri et al., 2020) but with lower speciation sensitivity.
In this study, we use the varved sediment record of Lake Jaczno (NE Poland) to explore the specific conditions and mechanisms of trophic and oxygen state changes in the Holocene, under changing climatic and environmental conditions. Our research has been guided by the following questions: (i) which conditions drove algae dynamics and oxygen state changes in the Holocene before any significant human intervention? (ii) How did climate, catchment vegetation and erosional input affect the phototrophic community in the lake? And (iii) how does the current trophic state and mixing regime of the lake compare with the past? For this, we combined a high-resolution HSI-inferred record of $T \mathrm{Chl}$ and Bphe, X-ray fluorescence (XRF) elemental data, and a low-resolution pigment record using HPLC analysis with high compound specificity, which cannot be achieved by the HSI record. Our dataset was compared with vegetation and temperature reconstruction data to investigate the environmental conditions at times of aquatic primary production and bottom-water oxygenation changes. Lake Jaczno provides ideal conditions to answer these questions. It contains an entirely varved Holocene sediment record, which has so far only been analyzed for the last 1700 years for productivity, anoxia (Butz et al., 2016, 2017) and historical land use (Poraj-Górska et al., 2017). Pollen records have revealed that human pressure was low until the 17 th century, when landscapes opened and agriculture intensified (Marcisz et al., 2020). Therefore, this site provides a unique opportunity for a long-term Holocene assessment of the natural causes and dynamics of meromixis and hypoxia with limited anthropogenic impact until historic times.

\section{Study site}

Lake Jaczno $\left(54^{\circ} 16^{\prime} 25.5^{\prime \prime} \mathrm{N}, 22^{\circ} 52^{\prime} 15.9^{\prime \prime} \mathrm{E}\right.$; $163 \mathrm{~m}$ a.s.1.; Fig. 1a) is a small, $26 \mathrm{~m}$ deep, exorheic, kettle-hole lake formed some time after the Weichselian deglaciation at ca. $15 \mathrm{ka}$ in the Suwałki Lakeland in NE Poland (Krzywicki, 2002). Lake Jaczno has a total surface area of $0.41 \mathrm{~km}^{2} \mathrm{sep}-$ arated into five distinct basins with narrow sills. It is fed by three permanent inflows ( $\mathrm{N}$ and $\mathrm{W}$ ) and one outflow in the south (Fig. 1b). Jaczno is classified as dimictic and mesotrophic (Tylmann et al., 2013) with incomplete mixing or possibly even meromixis during some years (Butz et al., 2016). Butz at al. (2017) found that anoxic and even meromictic conditions were established naturally for most of the past 1700 years. Meromixis was interrupted repeatedly following sediment slumping or flood events.

Microscopic and geochemical analyses of the sediments of Lake Jaczno have revealed seasonal layers (calcareous biogenic varves) with a complex succession of diatoms and calcite, detrital siliciclastic material (quartz, clays), organic fragments, and finally amorphous organic matter (Tylmann et al., 2013; Butz et al., 2016; Poraj-Górska et al., 2017). The lake is surrounded by steep slopes and gullies with ephemeral 

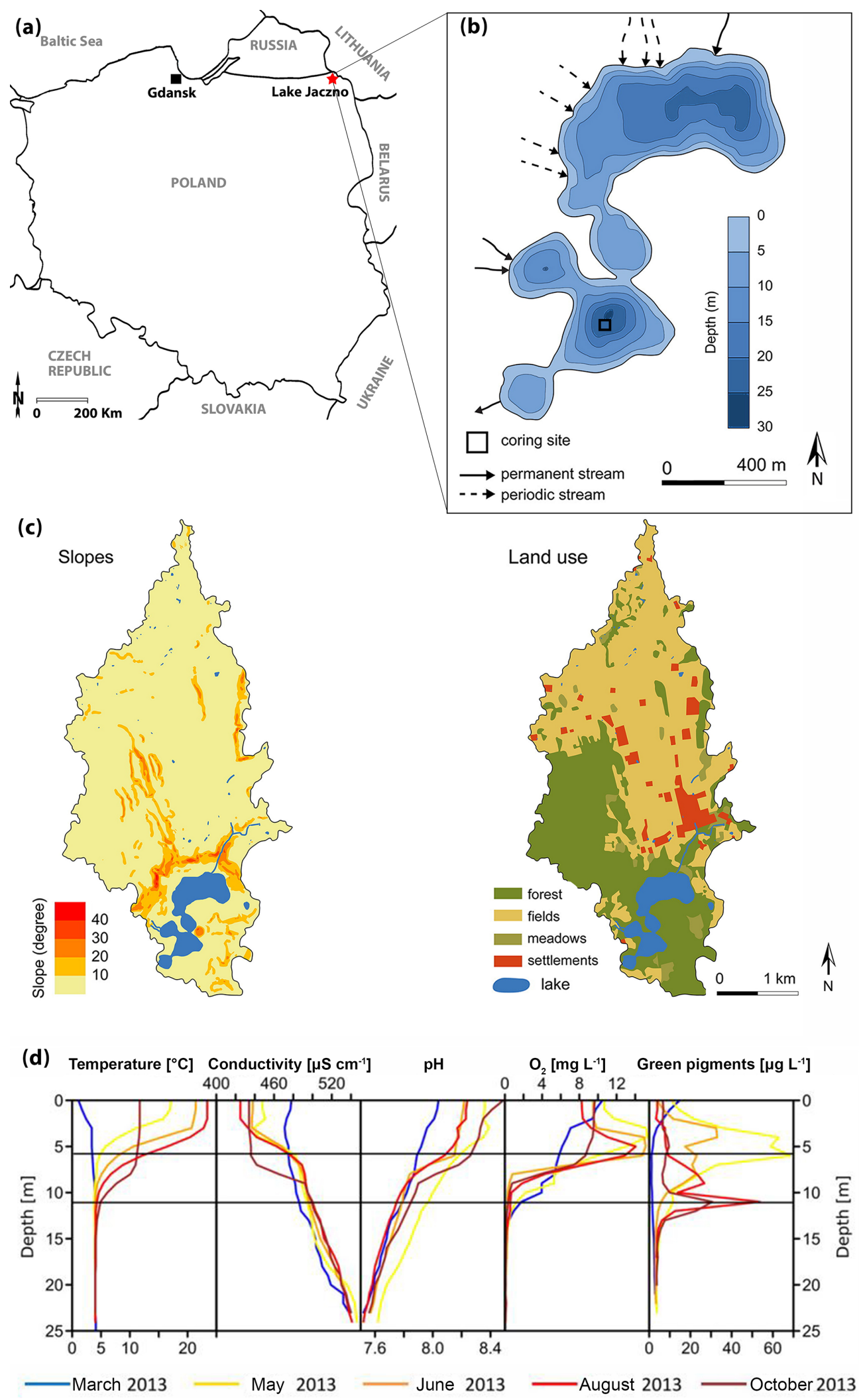

Figure 1. (a) Localization of Lake Jaczno. (b) Lake bathymetry (modified from Poraj-Górska et al., 2017) and coring position. (c) Slopes and land use maps of the catchment (modified from Poraj-Górska et al., 2017). (d) Seasonal limnological parameters in 2013 CE (Butz et al., 2016). 
or perennial water flow, transporting detrital material to the lake (Fig. 1c).

The catchment area (ca. $9 \mathrm{~km}^{2}$ ) is covered by glacial tills, sands and fluvioglacial deposits. Modern soils are classified as Cambisols and podzols in the northern part and Ferralic Cambisols in the southern part of the catchment. Agricultural lands dominate in the central and northern parts and forests in the southern parts (Fig. 1c). The lake is surrounded by peatlands and forests dominated by birch, alder and spruce (Weisbrodt et al., 2017). The climate of the region is continental with a mean annual temperature of $6.8^{\circ} \mathrm{C}$ and mean annual precipitation of $600 \mathrm{~mm}$ (IMGW-PIB, 2017). The lakes in the area typically remain ice-covered from December to March (Amann et al., 2014).

Archeological investigations in the Suwałki region indicate sparse or only seasonal human occupation during the Mesolithic and Neolithic (10000-3800 cal BP) (Engel and Sobczak, 2012). Around $2000 \mathrm{cal}$ BP human presence increases in the region with stronghold settlements, animal husbandry and fishing (Kinder et al., 2019). Yet, the area around Lake Jaczno remained isolated from human influences (Marcisz et al., 2020). Pollen and charcoal data and increased soil erosion indicate extensive forest clearance, forest fires and intensified agriculture, suggesting permanent settlements and higher human impact from $500 \mathrm{cal} \mathrm{BP}$, especially after 150 cal BP ( $1800 \mathrm{CE}$ ) (Kinder et al., 2019; Marcisz et al., 2020). The 1970s are marked by a regeneration of forest cover and a significant increase in fertilizer use in agriculture (Poraj-Górska et al., 2017; Kinder et al., 2019), which markedly increased lake primary production (Butz et al., 2016; Poraj-Górska et al., 2017).

\section{Materials and methods}

Two parallel cores that were ca. $12.5 \mathrm{~m}$ long were retrieved in September 2017, using a Uwitec piston corer. The coring site was located at the deepest part ( $24 \mathrm{~m}$ water depth) of the lake in the southern basin that is protected from direct external inputs (Fig. 1b). The cores were split lengthwise and then described following Schnurrenberger et al. (2003) and the Munsell color chart (Munsell Color (Firm), 2010). Flood deposits and slumps were identified based on grain size, mineral content and sediment structure. First, the core halves were analyzed using non-destructive methods, and further analytical measurements were performed after subsampling. The sampling interval for loss on ignition (LOI); carbon, hydrogen and nitrogen analysis (CNS); and dry-bulk density analysis was $10 \mathrm{~cm}$ (ca. 80-year resolution, discrete sampling). For the HPLC and spectrophotometer analysis, 46 discrete samples $\left(1-2 \mathrm{~cm}^{3}\right)$ were taken every ca. $30-35 \mathrm{~cm}$ (ca. 230-year resolution) taking into account the HSI scanning data and optimization for the proxy-to-proxy calibration of the HSI indices with spectrophotometer data (Butz et al., 2015). The top $10 \mathrm{~cm}$ (last ca. 50 years) was subsampled continuously every $1 \mathrm{~cm}$.

The chronology is based on 18 radiocarbon accelerator mass spectrometry (AMS) dates on taxonomically identified terrestrial plant macrofossils (Table 1) measured at the Laboratory for the Analysis of Radiocarbon at the University of Bern. Samples with $<300 \mu \mathrm{g} C$ were measured using the gassource input of the Mini Carbon Dating System (MICADAS) (Szidat et al., 2014; Zander et al., 2020). The age-depth model was calculated using bacon (rbacon v. 2.4.2) (Blaauw and Christen, 2011; Blaauw et al., 2020) and the IntCal13 calibration curve (Reimer et al., 2013). Event layers $(>3 \mathrm{~cm}$ ) and slumps were excluded from the age calculation (Fig. 2). According to changes in lithology, we used model parameters that allowed for a higher sedimentation rate in the lowermost $137 \mathrm{~cm}$ (Fig. 2).

XRF scanning was performed at continuous $2 \mathrm{~mm}$ steps using an ITRAX $\mu$ XRF core scanner (exposure time $20 \mathrm{~s}$, $30 \mathrm{kV}$ and $50 \mathrm{~mA}$ ) equipped with a $\mathrm{Cr}$ tube at the University of Bern. The results are given as counts (peak area). From the detected elements, Ti was used as a proxy for erosional input from the catchment; $\mathrm{Ca}$ as a proxy for endogenic calcium carbonates; $\mathrm{Si} / \mathrm{Ti}$ as a proxy for biogenic silica; and $\mathrm{S}$, $\mathrm{Fe}, \mathrm{Mn}$ and $\mathrm{Mn} / \mathrm{Fe}$ as proxies for changing redox conditions (Koinig et al., 2003; Croudace and Rothwell, 2015).

Hyperspectral imaging scanning (HSI) was performed on the freshly oxidized core halves using a Specim PFD-CL-65V10E camera (400 to $1000 \mathrm{~nm}$ spectral range, $2.8 \mathrm{~nm}$ spectral resolution). We used a spatial resolution of $\sim 68 \mu \mathrm{m}$ per pixel with a spectral sampling of $1.57 \mathrm{~nm}$. Data were processed using ENVI software version 5.4 (Exelis Visual Information Solutions, Boulder, Colorado) following Butz et al. (2015). The relative absorption band depths (RABDs) were calculated based on spectral endmember analysis in ENVI. RABD 673 (spectral region 590-730 nm) was used to detect chlorophyll $a$ and $b$ and their diagenetic products $(T \mathrm{Chl})$ and served as a proxy for aquatic primary production (Leavitt and Hodgson, 2001). RABD 845 (spectral region $790-895 \mathrm{~nm}$ ) was used to detect total bacteriopheophytin $a$ and $b$ (Bphe) (Butz et al., 2015, 2016), which is a proxy for anoxia and meromixis as described in Makri et al. (2020). Bphe $a$ and $b$ is produced by anoxygenic phototrophic purple sulfur and nonsulfur bacteria that proliferate in illuminated anoxic habitats (Yurkov and Beatty, 1998; Madigan and Jung, 2009). Green sulfur bacteria produce bacteriochlorophyll $c, d$ and $e$, which do not absorb in the $\mathrm{RABD}_{845}$ range. Therefore, HSI-inferred Bphe reflects purple-bacteria abundance.

The spectral indices were calibrated with absolute pigment concentrations of 46 selected sediment samples $\left(1 \mathrm{~cm}^{3}\right)$ measured by spectrophotometry (Shimadzu UV-1800). Pigments were extracted using pure acetone. The supernatant was evaporated under nitrogen, and extracts were subsequently redissolved in $2 \mathrm{~mL}$ of pure acetone (method adapted from Schneider et al., 2018). For the calculation of Bphe 
Table 1. Radiocarbon age results and calibrated ages. Uncertainties for ${ }^{14} \mathrm{C}$ ages refer to $68 \%$ probabilities $(1 \sigma)$, whereas ranges of calibrated ages refer to $95 \%$ probabilities $(2 \sigma)$. Outlier samples are marked with an asterisk. The abbreviation indet denotes indeterminable; dicot denotes dicotyledonous.

\begin{tabular}{|c|c|c|c|c|c|c|}
\hline Sample ID & Material & $\begin{array}{r}\mathrm{C} \text { mass } \\
(\mu \mathrm{g} \mathrm{C})\end{array}$ & $\begin{array}{r}\text { Age }{ }^{14} \mathrm{C} \\
(\mathrm{BP})\end{array}$ & $\begin{array}{r}\text { Age } \\
(\mathrm{calBP})^{\mathrm{a}}\end{array}$ & $\begin{array}{l}\text { Age range } \\
(\text { cal BP })^{\mathrm{b}}\end{array}$ & Graphite or gas \\
\hline BE-10957.1.1 & $\begin{array}{l}\text { Betula alba fruit, woody scale, } \\
\text { Pinus sylvestris needle base }\end{array}$ & 104 & $132 \pm 64$ & 142 & $0-284$ & gas \\
\hline BE-10958.1.1 & $\begin{array}{l}\text { Betula alba fruit scale, woody } \\
\text { scale, dicot leaf fragment }\end{array}$ & 219 & $482 \pm 44$ & 755 & $679-904$ & graphite \\
\hline BE-10959.1.1 & $\begin{array}{l}\text { Pinus sp. periderm, coniferous } \\
\text { wood and periderm fragment, } \\
\text { Betula alba fruit fragments, } \\
\text { coniferous scales }\end{array}$ & 118 & $872 \pm 55$ & 790 & $694-912$ & graphite \\
\hline BE-10960.1.1 & $\begin{array}{l}\text { Pinus sp. periderm, Betula alba } \\
\text { fruit fragments, conifer scale, Pinus } \\
\text { sp. } \\
\text { periderm, Betula alba fruit } \\
\text { fragments }\end{array}$ & 64 & $1460 \pm 67$ & 1364 & $1283-1522$ & gas \\
\hline BE-10961.1.1 & $\begin{array}{l}\text { Betula alba fruit fragments, conifer } \\
\text { scale, Betula alba fruit, } \\
\text { semi-charred periderm }\end{array}$ & 19 & $1781 \pm 127$ & 1706 & 1410-1987 & gas \\
\hline BE-10962.1.1 & $\begin{array}{l}\text { Alnus glutinosa fruit, Betula alba } \\
\text { fruit fragments, needle or leaf indet, } \\
\text { male anther indet }\end{array}$ & 268 & $2321 \pm 39$ & 2341 & $2180-2458$ & graphite \\
\hline BE-10963.1.1 & $\begin{array}{l}\text { Betula alba fruit fragments, Pinus } \\
\text { sp. periderm, male anther indet, } \\
\text { Betula alba fruit fragments, Pinus } \\
\text { sp. periderm, conifer scales }\end{array}$ & 73 & $2677 \pm 69$ & 2801 & $2545-2959$ & gas \\
\hline BE-10964.1.1 & $\begin{array}{l}\text { Betula alba fruit fragments, Pinus } \\
\text { sp. periderm, male anther indet, } \\
\text { Betula alba fruit fragments }\end{array}$ & 74 & $3229 \pm 72$ & 3458 & $3259-3633$ & gas \\
\hline BE-10965.1.1 & $\begin{array}{l}\text { Alnus glutinosa fruit fragment, } \\
\text { Betula alba fruit fragments, conifer } \\
\text { scales, dicot leaf fragments }\end{array}$ & 130 & $3758 \pm 60$ & 4125 & $3927-4383$ & graphite \\
\hline BE-10966.1.1 & $\begin{array}{l}\text { Male anther indet, dicot leaf } \\
\text { fragments, conifer scales, indet } \\
\text { scale, wood indet }\end{array}$ & 399 & $4322 \pm 36$ & 4887 & $4836-4972$ & graphite \\
\hline BE-10967.1.1 & $\begin{array}{l}\text { Dicot leaf fragments, indet scale, } \\
\text { male anther indet }\end{array}$ & 428 & $4860 \pm 37$ & 5601 & $5491-5650$ & graphite \\
\hline BE-10968.1.1 & Dicot leaf fragments, wood remains & 348 & $5144 \pm 39$ & 5906 & $5753-5989$ & graphite \\
\hline BE-10969.1.1 & $\begin{array}{l}\text { Dicot leaf fragments, indet } \\
\text { periderm, wood remains }\end{array}$ & 183 & $5998 \pm 57$ & 6839 & $6678-6977$ & graphite \\
\hline BE-10970.1.1 & Deciduous woody scale & 365 & $6153 \pm 41$ & 7062 & $6942-7166$ & graphite \\
\hline BE-10971.1.1 & $\begin{array}{l}\text { Betula alba fruit fragments, Pinus } \\
\text { sp. periderm, conifer scale, wood } \\
\text { indet }\end{array}$ & 111 & $6699 \pm 79$ & 7567 & $7439-7674$ & graphite \\
\hline BE-10972.1.1* & $\begin{array}{l}\text { Pinus sylvestris needle fragments, } \\
\text { wood indet }\end{array}$ & 58 & $8291 \pm 99$ & 9279 & 9029-9475 & gas \\
\hline
\end{tabular}


Table 1. Continued.

\begin{tabular}{|c|c|c|c|c|c|c|}
\hline Sample ID & Material & $\begin{array}{r}\mathrm{C} \text { mass } \\
(\mu \mathrm{g} \mathrm{C})\end{array}$ & $\begin{array}{r}\text { Age }{ }^{14} \mathrm{C} \\
(\mathrm{BP})\end{array}$ & $\begin{array}{r}\text { Age } \\
(\text { cal BP })^{\mathrm{a}}\end{array}$ & $\begin{array}{l}\text { Age range } \\
(\text { cal BP })^{b}\end{array}$ & Graphite or gas \\
\hline BE-10973.1.1 & $\begin{array}{l}\text { Dicot leaf fragments, deciduous } \\
\text { periderm, wood indet }\end{array}$ & 996 & $8018 \pm 22$ & 8896 & $8778-9007$ & graphite \\
\hline BE-10974.1.1 & $\begin{array}{l}\text { Betula alba fruit fragments, Pinus } \\
\text { sylvestris needle fragments, dicot } \\
\text { leaf fragments }\end{array}$ & 117 & $8094 \pm 91$ & 9019 & $8651-9287$ & gas \\
\hline BE-10975.1.1* & $\begin{array}{l}\text { Pinus sylvestris needle fragments, } \\
\text { Betula alba fruit fragments, indet } \\
\text { periderm }\end{array}$ & 280 & $8715 \pm 54$ & 9677 & 9548-9887 & graphite \\
\hline BE-10976.1.1* & $\begin{array}{l}\text { Dicot leaf fragments, male anther } \\
\text { indet, conifer needle tip, indet } \\
\text { periderm }\end{array}$ & 308 & $12446 \pm 69$ & 14580 & $14198-14994$ & graphite \\
\hline BE-10977.1.1 & $\begin{array}{l}\text { Dicot leaf fragments, Pinus sp. } \\
\text { periderm, woody scale }\end{array}$ & 999 & $8388 \pm 22$ & 9440 & $9318-9479$ & graphite \\
\hline
\end{tabular}

${ }^{\mathrm{a}}$ Median probability (Stuiver and Reimer, 1993). ${ }^{\mathrm{b}}$ Calibrated age range with the IntCal13 calibration curve (Stuiver and Reimer, 1993; Reimer et al., 2013).

concentrations, we used the molar extinction coefficient for Bphe $a$ by Fiedor et al. (2002). For TChl, we applied the molar extinction coefficient for chlorophyll types and chlorophyll derivatives by Jeffrey et al. (1975). The performance of the proxy-to-proxy linear regression models was assessed using the coefficient of determination $\left(R^{2}\right)$ and the root mean square error of prediction (RMSEP) (Butz et al., 2015) run in R ( $\mathrm{R}$ Core Team, 2015). The calibration model for $T C h l$ showed an $R^{2}$ of $0.91(p<0.001)$ and an RMSEP of $\sim 8 \%$ (Fig. S1a). The calibration model for Bphe showed an $R^{2}$ of $0.95(p<0.001)$ and an RMSEP $\sim 6 \%$ (Fig. S1b). The Shapiro-Wilk and the Kolmogorov-Smirnov tests of the residuals showed that they are most likely normally distributed, suggesting that inferences can be made with both models.

HPLC analysis was conducted on the same 46 samples used for the proxy-to-proxy calibration. Chlorophyll, chlorophyll derivatives and carotenoids were measured using ion-pairing reverse-phase HPLC (Mantoura and Llewellyn, 1983; Hurley, 1988). The system used a ultraviolet-visible (UV-VIS) detector set at 460 and $656 \mathrm{~nm}$ for carotenoids and chloropigments, respectively. The results were corrected for water content and expressed in $\mathrm{nmol} \mathrm{g} \mathrm{OM}^{-1}$ (Züllig, 1982; Guilizzoni et al., 1983; Lami et al., 1994). According to Jeffrey et al. (2011) and Guilizzoni and Lami (2002), chlorophyll $a, \beta \beta$-carotene, pheophytin $a$ and pheophytin $b$ are considered indicators of total algal biomass. Chlorophyll $b$ and lutein are associated with green algae. $B$-Carotene, dinoxanthin (pyrophytes), diadinoxanthin (siliceous algae), fucoxanthin (diatoms), diatoxanthin (chrysophytes) and alloxanthin (cryptophytes) are related to brown algae. Echinenone and zeaxanthin are associated with most taxa of blue-green algae, and myxoxanthophyll and canthaxanthin are associated with colonial and filamentous cyanobacteria (Leavitt and Hodgson, 2001). k-Myxol (4-keto-myxol-2'methylpentoside) is associated with $\mathrm{N}$-fixing cyanobacteria (Anabaena flos-aquae) (Kosourov et al., 2016). Pheophorbide $a$ is a degradation product of Chl $a$ transformed by microbial processes and used as an indicator of grazing (Bianchi and Findlay, 1991; Cartaxana et al., 2003). In the phototrophic bacteria community, BChl $a$ is common to all anoxygenic phototrophic purple bacteria. Okenone (Chromatium sp.) is associated with purple sulfur bacteria (PSB), whereas spheroidene and spheroidenone (Rhodopseudomonas sphaeroides) are related to purple nonsulfur bacteria (PnSB). Both groups are able to oxidize sulfide. Yet, PSB store any $S^{0}$ formed intracellularly, whereas PnSB do so outside the cell (Madigan and Jung, 2009). The main difference between the two groups is that PSB are strong photoautotrophs, whereas PnSB are physiologically versatile and can grow well both phototrophically and in darkness via fermentation or anaerobic respiration (Madigan and Jung, 2009). $R$. sphaeroides is also an excellent $\mathrm{N}$-fixing bacterium. Oxygen tolerance varies among species, with $R$. sphaeroides being able to grow under vigorous aeration. Spheroidenone is produced by $R$. sphaeroides only when even small amounts of oxygen are present (Züllig, 1989). Hence, the presence of spheroidenone is used as an indication of better oxygen conditions, whereas the presence of spheroidene with the parallel absence of spheroidenone is used as an indication of meromictic conditions (Züllig, 1989; Guilizzoni and Lami, 2002). Isorenieratene is associated with GSB (Chlorobium sp.). GSB have low light requirements and can cope with low light availability, occupying deeper layers in stratified lakes (Montesinos et al., 1983). Hence, a dominance of GSB over 
PSB is used as an indicator of a deeper oxic-anoxic boundary (Montesinos et al., 1983; Itoh et al., 2003).

Total organic carbon (TOC) was determined by loss on ignition (LOI; Heiri et al., 2001). Total carbon (TC) and total nitrogen (TN) were measured with a CNS analyzer (Elementar vario EL cube). Total inorganic carbon (TIC) was calculated by the difference between TC and TOC (Enters et al., 2010). The TOC / TN ratio was used to infer changes in OM sources (Meyers, 2003). The lithogenic flux was calculated based on the residual calculation after removing the organic matter and carbonate fraction by LOI.

Statistical analysis was performed in R (R Core Team, 2015). To define the sedimentary lithotypes, we performed a hierarchical unconstrained clustering on the geochemical proxies (XRF - Ti, $\mathrm{Ca}, \mathrm{Si} / \mathrm{Ti}, \mathrm{Si}, \mathrm{S}, \mathrm{Fe}, \mathrm{Mn}, \mathrm{Mn} / \mathrm{Fe}$; HSI - TChl and Bphe; TOC, TIC, TN, TOC / TN data; Fig. 3) using the Euclidean distance matrix and the ward.D2 clustering method (Murtagh and Legendre, 2014). On the same dataset, we performed a principal component analysis (PCA) with the samples grouped based on the unconstrained clustering to investigate the relationships between the lithotypes and the geochemical variables (Fig. S2). The data were log transformed and scaled before statistical analysis. We performed a redundancy analysis (RDA) using the vegan package (Oksanen et al., 2016) in $\mathrm{R}$ to relate the pigment matrix i.e., HPLC- and HSI-inferred pigment concentrations (Hellinger-transformed variables), to the environmental variables i.e., temperature (Heikkilä and Seppä, 2010), arboreal pollen (AP), non-arboreal pollen (NAP) (Kinder et al., 2019; Marcisz et al., 2020) and lithogenic flux (log-transformed variables). The elements were plotted using scaling 2 (see Borcard et al., 2011, pp. 166-167). This analysis was followed by a permutation test in $\mathrm{R}$ to test for significance in the redundancy analysis (Legendre and Legendre, 1998; Borcard et al., 2011). The zones of pigment data were defined by constrained clustering using the Bray distance and ward.D2 linkage method in R.

\section{Results and interpretation}

\subsection{Chronology}

The age-depth model (Fig. 2) reveals a basal age of ca. $9500 \mathrm{cal} \mathrm{BP}$. The model shows a stationary distribution, matching prior and posterior accumulation rates, and a smooth sediment accumulation as indicated by its memory or variability (Fig. 2). Three radiocarbon samples (Fig. 2, in red) have calibrated ages that do not fit with the $95 \%$ confidence interval. Based on the lithology and the much older ages, these samples were considered to contain reworked carbon and were excluded from the bacon model. The sediment sequence is entirely laminated throughout the Holocene showing regular continuous sedimentation without any hiatus. In the lowermost section $(1257-1120 \mathrm{~cm})$, sedimentation rates
(SR) are relatively high $\left(0.5 \mathrm{~cm} \mathrm{yr}^{-1}\right)$ and the mean age error $(95 \%$ confidence interval) is ca. \pm 160 years. Numerous event layers and slumps characterize the part between 1120 and $800 \mathrm{~cm}$ where the SR is ca. $0.2 \mathrm{~cm} \mathrm{yr}^{-1}$ and the mean age error is ca. \pm 200 years. From $800 \mathrm{~cm}$ to the top, the sediment is continuously varved and the SR is $0.1 \mathrm{~cm} \mathrm{yr}^{-1}$ $\left(0.2 \mathrm{~cm} \mathrm{yr}^{-1}\right.$ in the last 500 years). The mean age error in this section is ca. \pm 140 years. The ages at the top $10 \mathrm{~cm}$ of the core (data shown in Fig. 4b) were calculated by extrapolation of the radiocarbon chronology to the sediment surface. A stratigraphic correlation with the ${ }^{210} \mathrm{~Pb}$-dated cores from Butz et al. (2016) showed an age error of \pm 5 years for this section.

\subsection{Lithotypes and biogeochemical proxies}

Figure 3 shows the biogeochemical data that defined four sedimentary lithotypes A-D. Figure S3 (Supplement) shows the RGB images and the biogeochemical composition of selected close-ups within the sediment sequence. Lithotype A and B appear in segments between ca. 9500-6800 cal BP (Fig. 3). Lithotype A, at the bottom part (9500-9200 cal BP), consists of light-greenish-grey (GLEY $27 / 2$ ) fine sand and continues with pale-yellow (2.5Y 7/3) and grey (2.5Y 5/1) laminations with light-greenish-grey silty lenticular bedding. This part is characterized by high detrital inputs (Ti, lithogenic flux), moderate carbonate content (Ca, TIC), low production and biogenic silica (HSI TChl, $\mathrm{Si} / \mathrm{Ti}$ ), and low TOC. Low HSI Bphe and $\mathrm{S}$ and higher $\mathrm{Mn} / \mathrm{Fe}$ ratios indicate effective oxygenation of bottom waters. From ca. 9200$8500 \mathrm{cal} \mathrm{BP}$, lithotype B is introduced and is characterized by slightly higher production (HSI $T \mathrm{Chl}$ ) and biogenic silica $(\mathrm{Si} / \mathrm{Ti})$; carbonates (TIC, Ca), TOC and TN contents increase, whereas higher S, Fe and HSI Bphe and lower Mn/Fe ratios indicate the development of anoxic (sulfidic) conditions. Between ca. 8500-6800 cal BP, lithotype A continues with varved sediments; starting with biogenic pale-yellow $(2.5 \mathrm{Y} 7 / 3)$ and grey $(2.5 \mathrm{Y} 5 / 1)$ varves with intercalated reddish brown (2.5YR 5/4) and reddish black (2.5YR 2.5/1) laminations rich in clastic material and iron oxides. In the second half of this part, varves are less well preserved with several intercalated clastic-rich laminations. Based on color, layer thickness and grain size, we interpret these intercalated layers as event (flood) deposits. In this period, lithotype A is characterized by high detrital input ( $\mathrm{Ti}$, lithogenic flux); primary production (HSI $T \mathrm{Chl}$ ) remains unchanged, and carbonates (Ca, TIC) show increased variability. Biogenic silica $(\mathrm{Si} / \mathrm{Ti}), \mathrm{TOC}$ and $\mathrm{Fe}$ slightly decrease. $\mathrm{S}$ decreases, HSI Bphe is very low or absent, and $\mathrm{Mn} / \mathrm{Fe}$ increases, suggesting better oxygen conditions.

Lithotype C occurs between ca. 6800-500 cal BP and consists mainly of light-grey (2.5YR) and dark-grey (2.5YR 4/1) fine biogenic varves, with some dispersed event layers that occur only at the beginning of this period until ca. $6000 \mathrm{cal} \mathrm{BP}$. This period is characterized by low ero- 


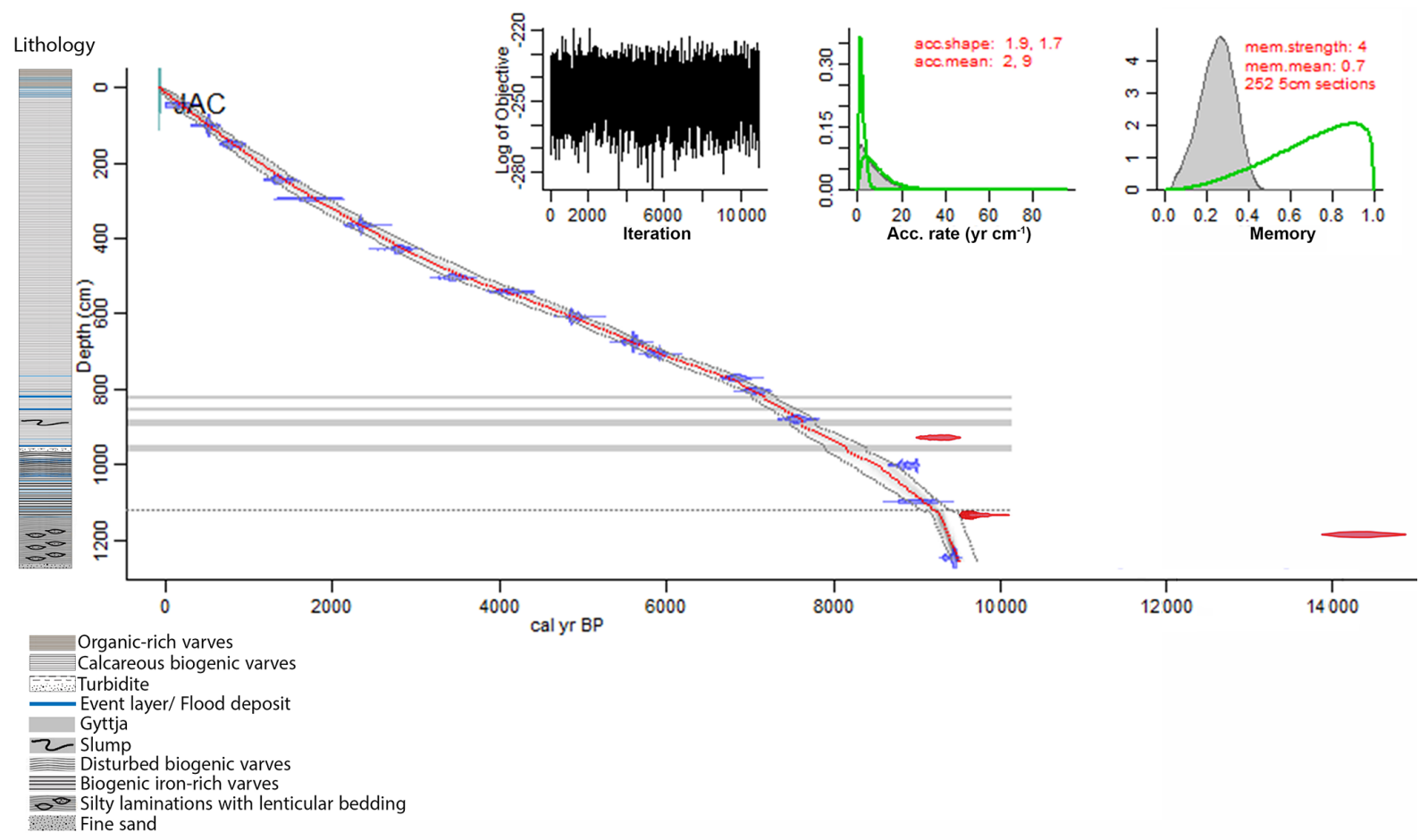

Figure 2. Age-depth model and lithology of Lake Jaczno. The red line is the modeled chronology using bacon (Blaauw and Christen, 2011; Blaauw et al., 2020); the excluded outliers are shown in red. The dotted grey lines indicate the $95 \%(2 \sigma)$ probabilities. The horizontal grey areas indicate event layers $(>3 \mathrm{~cm})$ excluded from the model. The horizontal dashed line marks the boundary of a higher sedimentation rate (model parameter). The upper left inset shows the log objective vs. MCMC iteration that indicates a stationary distribution. The middle and right insets indicate the distributions (prior in green, posterior in grey) for the accumulation rate and the memory, respectively.

sional input (Ti, lithogenic flux), gradually increasing production (HSI $T \mathrm{Chl}$ ) and TOC content, fluctuating biogenic silica $(\mathrm{Si} / \mathrm{Ti})$, and constantly high carbonate content $(\mathrm{Ca}$, TIC). S counts are minimal. HSI Bphe is mostly present, suggesting the development of anoxic conditions in the hypolimnion. $\mathrm{Mn} / \mathrm{Fe}$ seems to fluctuate, with higher values when HSI Bphe is lower and vice versa.

Lithotype D occurs from ca. 500 cal BP to the present and consists of biogenic pale-yellow (2.5Y 7/3), grey (2.5Y 5/1) and dark-grey $(2.5 \mathrm{Y} 4 / 1)$ calcareous biogenic varves. This period is characterized by instances of higher detrital input (Ti) and several intercalated event (flood) layers. Mn counts also increase. Primary production (HSI TChl), TOC and TN reach maximum levels, whereas biogenic silica and carbonates (Ca, TIC) decrease. HSI Bphe reaches maximum values at the top, suggesting persistent anoxia in this part. The $\mathrm{Mn} / \mathrm{Fe}$ ratio and HSI Bphe show opposite fluctuations indicating phases of better oxygen conditions when Bphe is absent.

\subsection{HPLC pigment stratigraphy}

Figure 4 presents the pigment dataset of individual chlorophyll types and carotenoids measured by HPLC in the Holocene (Fig. 4a), and for the last 50 years (Fig. 4b). The pigments are grouped according to their taxonomic relation, and the zones are defined by constrained clustering, which yielded boundaries that are similar to those of the sediment lithotypes (Fig. 3).

In zone I (ca. 9500-9200 cal BP), pigment concentrations are very low. Chromophytes are more abundant than green algae, especially cryptophytes (alloxanthin) and chrysophytes (fucoxanthin). Blue-green algae (echinenone, zeaxanthin) are present in low concentrations. Grazing (pheophorbide $a$ ) is low. In the purple-bacteria group, Chromatium species (okenone, PSB) are absent, whereas $R$. sphaeroides (spheroidene and spheroidenone, $\mathrm{PnSB}$ ) is present in low concentrations. Chlorobium sp. (isorenieratene, GSB) is present in traces.

In zone II (ca. 9200-6700 cal BP), pigment concentrations increase overall. Green algae (chlorophyll $b$, lutein) still have low concentrations, whereas chromophytes ( $\beta$-carotene) become more abundant, especially pyrophytes (dinoxanthin) and chrysophytes (diatoxanthin) which show a distinctive local maximum around $7300 \mathrm{cal}$ BP. Colonial filamentous cyanobacteria (canthaxanthin) appear in this zone. Grazing (pheophorbide $a$ ) starts increasing around $8300 \mathrm{cal}$ BP. Chromatium sp. (okenone, PSB) is mostly absent. $R$. sphaeroides (spheroidene and spheroidenone, PnSB) has moderate con- 


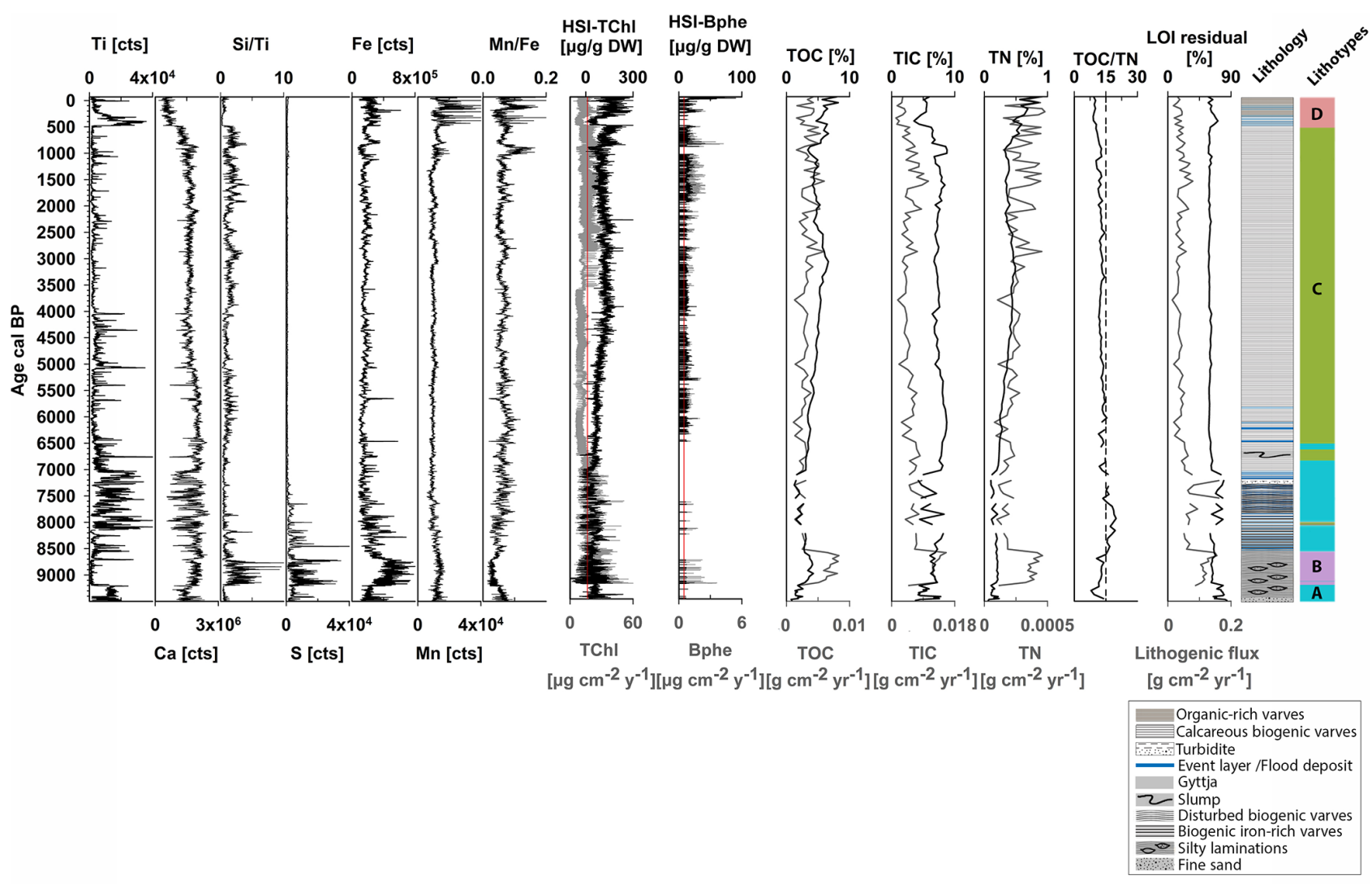

Figure 3. Selected biogeochemical proxies that defined the four sedimentary lithotypes A-D (in different colors) after unconstrained clustering and PCA (Fig. S2). On the right: sediment lithology based on visual examination.

centrations, whereas Chlorobium sp. (isorenieratene, GSB) reaches a maximum around $7300 \mathrm{cal} \mathrm{BP}$.

In zone III (6700-500 cal BP), most pigments' concentration increases gradually. Green algae (chlorophyll $b$ ) increase significantly. Chromophytes remain abundant. Diatoms and other siliceous algae (diadinoxanthin, fucoxanthin) and cryptophytes (alloxanthin) show a local maximum around $2000 \mathrm{cal}$ BP. Blue-green algae (echinenone, zeaxanthin) increase gradually. More colonial filamentous cyanobacteria (myxoxanthophyll) appear around $2300 \mathrm{cal} \mathrm{BP}$ and, together with zeaxanthin, reach a maximum around 2000 cal BP. N-fixing cyanobacteria $(k$-myxol) appear at ca. $5000 \mathrm{cal}$ BP. Chromatium sp. (okenone, PSB) appears in this zone and increases gradually. $R$. sphaeroides (spheroidene and spheroidenone, PnSB) also shows a gradual increase, whereas Chlorobium sp. (isorenieratene, GSB) decreases to minimum concentrations.

Zone IV (500 cal BP to present) is characterized by a further gradual increase in most pigments, reaching unprecedented maximum concentrations at the top. In more detail, Fig. $4 \mathrm{~b}$ shows the distribution of pigment concentrations in the last 50 years. Most pigments reach maximum values around 1997 CE. Chromatium sp. (okenone, PSB) has high concentrations, whereas $R$. sphaeroides is present producing only spheroidene and almost no spheroidenone. Chlorobium sp. (isorenieratene, GSB) shows only trace concentrations around $1997 \mathrm{CE}$.

\subsection{The relationships between land use, temperature and pigment stratigraphy}

We applied a redundancy analysis (RDA) to examine the response of our HPLC- and HSI-inferred pigment dataset to land use changes (arboreal pollen, AP, and non-arboreal pollen, NAP; Kinder et al., 2019; Marcisz et al., 2020), annual mean temperature variability (Heikkilä and Seppä, 2010) and catchment surface processes (lithogenic flux). Figure 5 shows the RDA ordination output in a triplot with the explanatory variables (in blue) and response variables (in red), as well as the samples divided into the four distinct zones defined by constrained clustering (see Sect. 4.3). The numerical output shows that the first two axes (RDA $120.95 \%$ and RDA $211.25 \%$ ) explain $36 \%$ of the variation (unadjusted values). The $R_{\text {adj }}^{2}$ for the constrained ordinations suggests that this model explains ca. $29 \%$ of the variation in the data. The permutation test on the unconstrained ordinations indicates that the first two axes are 


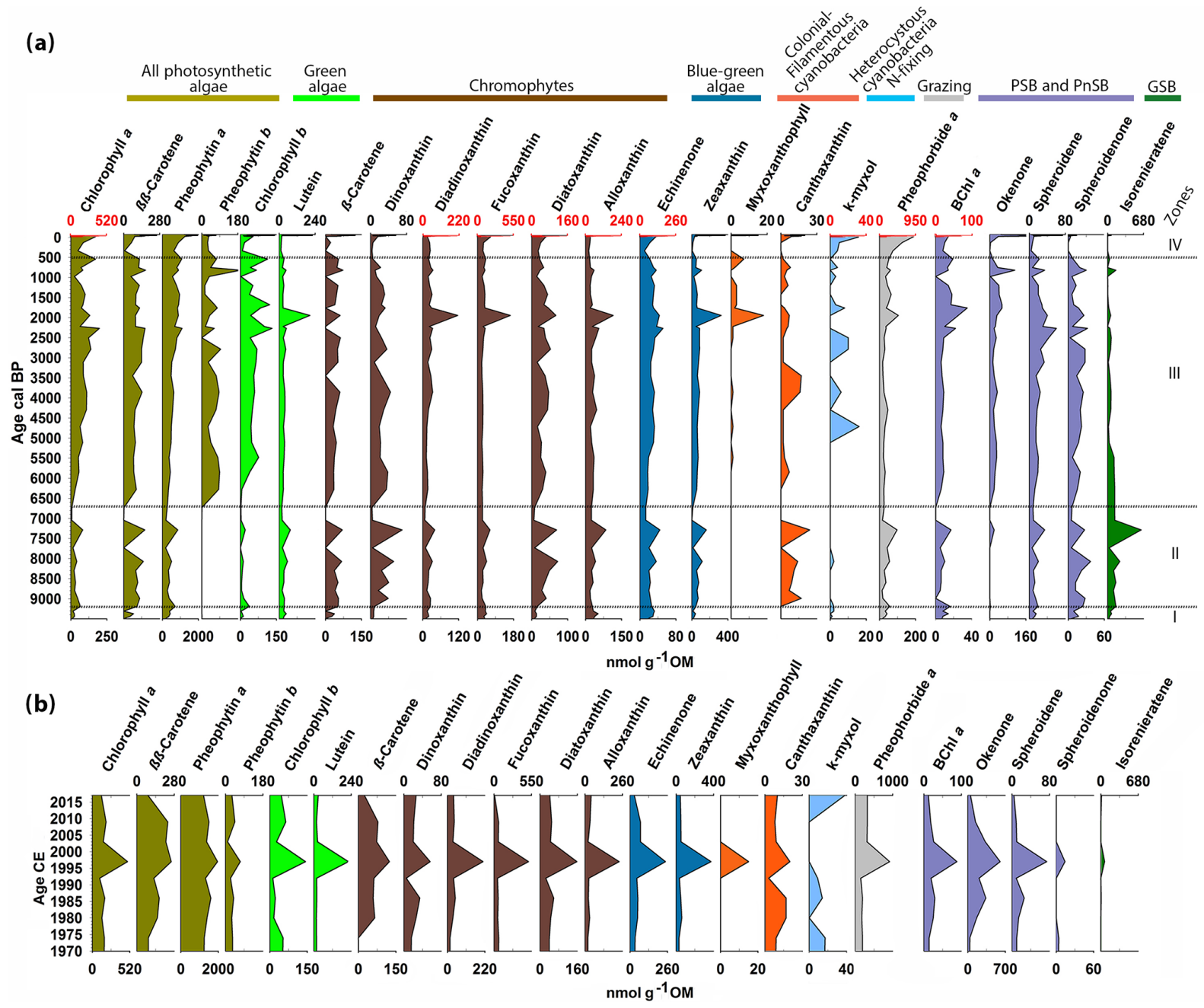

Figure 4. Chlorophyll, chlorophyll derivatives, carotenoids and bacterial pigments concentrations measured by HPLC (a) for the entire Holocene and (b) for the last 50 years. The zones are defined by constrained hierarchical clustering. The different colors indicate different algal groups based on the pigments' taxa affiliation. The occasional red scale on top marks the significantly higher concentrations of these pigments in the last 50 years.

significant $(p<0.001$; Table S1) and represent the data adequately.

The RDA triplot (Fig. 5) shows that AP and NAP play an important role in the distribution of the pigment data along the first axis (RDA 1). Lithogenic flux and temperature drive pigment variability along the second axis (RDA 2). Lithogenic flux is strongly correlated with siliceous algae (fucoxanthin, diadinoxanthin) and blue-green algae (echinenone), as well as with enhanced aquatic primary production (HSI $T \mathrm{Chl}$ ) by green algae (lutein) and cryptophytes (alloxanthin, $\beta$-carotene). Lithogenic flux is clearly anticorrelated with PSB (okenone, HSI Bphe) and Chl $a$. AP is mainly correlated with GSB pigments (isorenieratene), indicating a deeper oxic-anoxic boundary, and PnSB (spheroidene and spheroidenone) which suggest a more effective oxygenation of the water column. AP is also correlated with vari- ables indicating the presence of chromophyte (brown) algae, pyrophytes (dinoxanthin) and chrysophytes (diatoxanthin), as well as some blue-green algae (zeaxanthin). Higher lithogenic input and AP drive pigment variability in zones I and II. Temperature seems to be correlated with higher production of some green algae $(\mathrm{Chl} b$, pheophytin $b)$, increased cyanobacteria abundance ( $\beta \beta$-carotene, $\beta$-carotene) and colonial filamentous cyanobacteria (myxoxanthophyll, canthaxanthin). Temperature seems to drive pigment variability mainly in zone III. NAP is correlated with PSB production ( $B \mathrm{Chl} a$, HSI Bphe and okenone), overall higher primary production (Chl $a$, pheophytin $a$ ), higher grazing (pheophorbide $a$ ), and $\mathrm{N}$-fixing cyanobacteria ( $k$-myxol). NAP drives pigment variability in zone IV. 


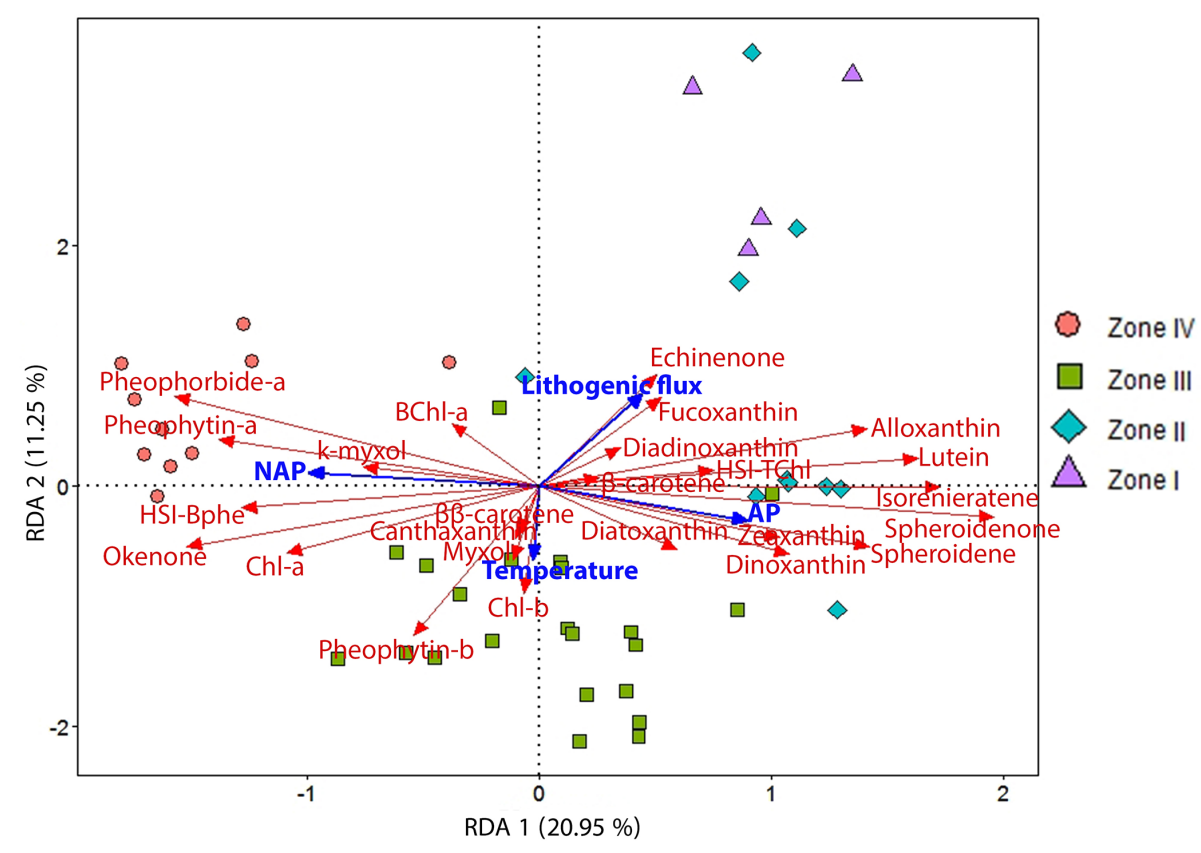

Figure 5. RDA triplot showing the explanatory variables (AP, NAP, temperature and lithogenic flux) in blue and the response variables (HPLC- and HSI-inferred pigment concentrations) in red. The samples are grouped according to the pigment zones (Fig. 4a).

\section{Discussion}

\subsection{Combining sedimentological and biogeochemical data to infer past lake production and bottom-water oxygenation}

The $12.5 \mathrm{~m}$ long and almost entirely varved sediment record of Lake Jaczno continuously spans the last ca. 9500 cal years BP (Fig. 2). The chronology is robust and exclusively based on terrestrial macrofossils. The lithology of Lake Jaczno (Fig. 3) revealed the deposition of frequent event layers between $8500-7000$ cal BP, which likely reflect a regional catchment or climatic signal as similar features have been observed, for the same period, in the nearby Lake Szurpiły (Kinder et al., 2020). The physical characteristics of the catchment favored the transport of lithogenic material into the lake (Fig. 3), thereby possibly affecting the density stratification, light availability and subsequently the phototrophic community dynamics. A proper assessment of these changes requires high-resolution data that are impossible to obtain using HPLC data alone. Yet, the combination of high-resolution (micrometer-scale) calibrated HSI bulk data for $T \mathrm{Chl}$ and Bphe, also combined with scanning $\mathrm{XRF}$ and compound-specific HPLC data, provides a unique opportunity for paleoproduction and paleooxygenation reconstructions at a sub-seasonal scale for multi-millenniallong records (Butz et al., 2017; Makri et al., 2020). This approach is directly applicable to diverse lacustrine (Butz et al., 2017; Schneider et al., 2018; Makri et al., 2020; Sanchini et al., 2020) and potentially marine environments (Hubas et al., 2011,2013 ) with uncertain past redox state changes.

The calibration of $\mathrm{RABD}_{673}$ and $\mathrm{RABD}_{845}$ to absolute pigment concentrations of green pigments (chlorophyll types and diagenetic products) and Bphe ( $a$ and $b)$, respectively, revealed robust calibration statistics (Fig. S1, supplementary material) with very low uncertainties (ca. 6\%-8\%) comparable to other studies (Butz et al., 2017; Schneider et al., 2018; Makri et al., 2020; Sanchini et al., 2020). Between ca. 9200 and 7000 cal BP, the calibration model of $\mathrm{RABD}_{673}$ for green pigments calculates negative concentrations (Fig. 3). This offset can be produced by matrix effects, i.e., the variability in the reflectance of the sediment matrix or substances that absorb in the same range as chlorophyll types and their diagenetic products $(590-730 \mathrm{~nm})$ (Makri et al., 2020). Interestingly, GSB (isorenieratene) peak between 9200 and 7000 cal BP (Fig. 4). GSB contain bacteriochlorophyll $c, d$ and $e$ that absorb in the same range as chlorophyll types and chlorophyll derivatives (Oren, 2011). This could indicate that a part of the $\mathrm{RABD}_{673}$ calibration error may be due to the increased GSB abundance. Nonetheless, the calibration statistics reveal an overall error of less than $8 \%$.

\subsection{Holocene production dynamics and chemocline evolution}

The presence of anoxygenic sulfur bacteria throughout our record, combined with chlorophyll types, carotenoids and geochemical evidence, suggests that euxinic conditions prevailed in Lake Jaczno for most of the past 9500 years. 
Nonetheless, the changing composition of photosynthetic sulfur bacteria indicates persisting but variable euxinia. Figure 6 summarizes the Holocene evolution of the relative abundance of PSB, PnSB and GSB, Chromatium (okenone) and Chlorobium (isorenieratene), the content of spheroidene and spheroidenone pigments produced by $R$. sphaeroides, and the high-resolution calibrated HSI $T \mathrm{Chl}$ and Bphe, with respect to lithogenic flux, climate variability (annual mean temperature) (Heikkilä and Seppä, 2010) and human impact (land use and vegetation cover; Kinder et al., 2019; Marcisz et al., 2020).

\subsubsection{Low trophic levels with a deep oxic-anoxic boundary}

In the period from 9500 to $6700 \mathrm{cal} \mathrm{BP}$, which corresponds to pigment zones I and II, the phototrophic bacteria population is dominated by GSB (Fig. 6). A small percentage of PnSB (R. sphaeroides) is present and seems to produce both spheroidene and spheroidenone during this time. Chromatium (okenone, PSB) is almost completely absent. Considering that $R$. sphaeroides produces spheroidenone only when even small amounts of oxygen are present (Züllig, 1989), we suggest that, in this period, euxinic conditions were already present but the strength or extent of anoxia was likely weak. HSI Bphe that corresponds to purple bacteria is very low. Anoxia is mainly a function of lake stratification and productivity. HSI $T \mathrm{Chl}$, which indicates total primary production, is still at low levels (Fig. 6). Indeed, the stratigraphy of individual pigments indicates low to moderate in-lake production, which mainly consists of chromophyte (brown) algae and some colonial cyanobacteria (canthaxanthin) (Fig. 4), also confirmed in the RDA (Fig. 5). Brown siliceous algae are well adapted and tolerant algae species that thrive in oligotrophic conditions in symbiosis with other algae species and bacteria (Bird and Kalff, 1986; Wetzel, 2001). Similar observations of algae composition were made in Lake Peipus (Tõnno et al., 2019; Estonia) and Lake Łazduny (Sanchini et al., 2020; NE Poland).

Temperature gradually increased, and a closed forest canopy with pine and birch and later elm, hazel and alder persisted in the catchment (Fig. 6) (Gałka, 2014). These provided shelter from wind and increased the nutrient pools in the catchment soils (Bajard et al., 2017). The closed forest canopy, combined with the deep and relatively small basin (relative depth $3.01 \%$ ), favors the establishment of a naturally anoxic hypolimnion (Zolitschka et al., 2015). Yet, it seems that enhanced permanent stratification was still not established in the lake. This phase of GSB dominance corresponds to a period of high lithogenic flux or highenergy sedimentation (Figs. 3, 6), as confirmed in the RDA (Fig. 5). Turbidity currents and underflows can increase nutrient availability and cause sporadic ventilation of bottom waters. Higher suspended matter and/or algal growth would decrease light availability at the oxic-anoxic boundary. Since
GSB and PnSB are more tolerant to low light intensities than PSB (Biebl and Pfennig, 1978; Parkin and Brock, 1980; Madigan and Jung, 2009), a dominance of GSB and presence of spheroidene and spheroidenone in the sediments is expected under these conditions. Similar observations were made in Lake Cadagno (Wirth et al., 2013). GSB often inhabit the lowermost part of stratified water bodies due to their efficient light capture (Manske et al., 2005; Imhoff, 2014). Higher abundance of GSB could also indicate a deep oxicanoxic boundary in the lake (Itoh et al., 2003; Antoniades et al., 2009).

\subsubsection{Gradually increasing trophy levels with a shallower oxic-anoxic boundary}

The period from 6700 to $500 \mathrm{cal} \mathrm{BP}$, which corresponds to pigment zone III, is characterized by a gradual shift in the phototrophic bacterial community to higher PSB abundance, especially after ca. 2000 cal BP (Fig. 6). GSB are present, inhabiting the anoxic layers below PSB, and seem to fluctuate as a function of the primary production in the oxic layer (HSI $T \mathrm{Chl}$ ) and related light availability (Montesinos et al., 1983). When production was higher in the oxic layers, Chromatium (okenone, PSB) increased and Chlorobium (isorenieratene, GSB) decreased. This is also confirmed by the individual pigment stratigraphy (Fig. 4). Green algae (chlorophyll $b$, lutein) and $\mathrm{N}$-fixing cyanobacteria ( $k$-myxol) increase markedly from ca. $5500 \mathrm{cal} \mathrm{BP}$, indicating a higher lake trophy than before, driven most probably by lake ontogeny and a gradual increase in nutrient availability. The appearance of $\mathrm{N}$-fixing cyanobacteria at that time agrees with this interpretation. Prolonged periods of anoxia leading to intense recycling of phosphorous from the sediments would decrease the $\mathrm{N}$ : $\mathrm{P}$ ratio in the water column promoting nitrogen fixation by $\mathrm{N}$-fixing algae (Howarth et al., 1999; Vitousek et al., 2002). Similar trends in lake trophy evolution are reported from nearby Lake Szurpiły (Kinder et al., 2019) and lakes Albano and Peipus (Lami et al., 2000; Guilizzoni and Lami, 2002; Tõnno et al., 2019). An increase in Chromatium (okenone, PSB) over Chlorobium (isorenieratene, GSB) with increasing lake trophy has been reported from other lakes, e.g., Lake Albano in Italy (Lami et al., 1994), Little Round Lake in Canada (Brown et al., 1984) and Lake Hamana in Japan (Itoh et al., 2003). R. sphaeroides (PnSB) is also present producing both spheroidene and spheroidenone, suggesting phases of effective aeration of bottom waters (Züllig, 1989).

The catchment is continuously densely forested, and human impact is very low (Fig. 6). The RDA points to a temperature-driven pigment variability in this zone but mainly for cyanobacteria abundance (Fig. 5). Cyanobacteria can benefit from higher water temperature, yet nutrient inputs have in most cases a much stronger and synergetic effect (Lürling et al., 2018). Temperature variability did not seem to have affected lake stratification directly. However, seasonal- 


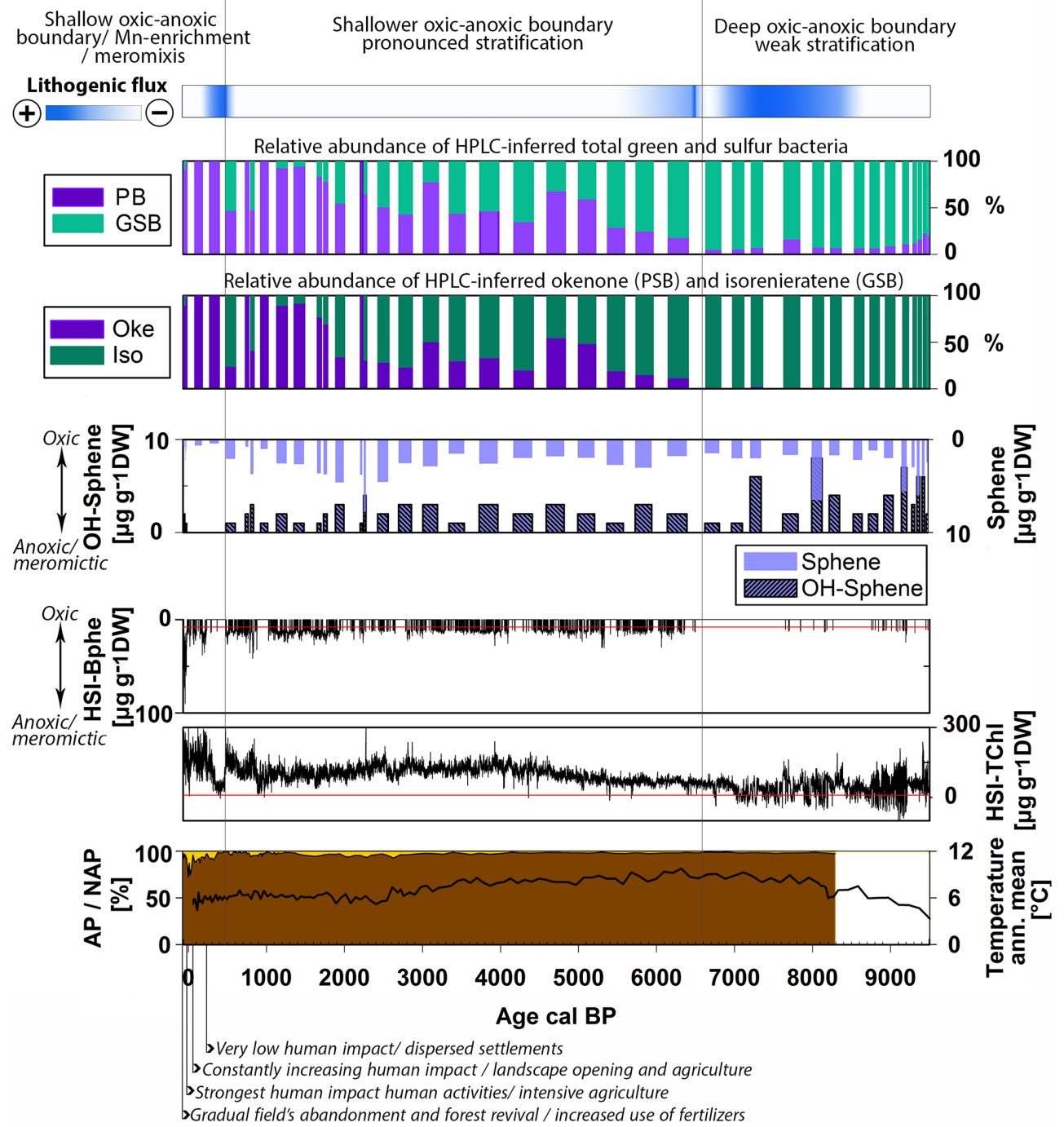

Figure 6. Holocene summary of the relative abundance of purple bacteria (sum of PSB and PnSB) and GSB, Chromatium (okenone, PSB) and Chlorobium (isorenieratene, GSB), the content of spheroidene and spheroidenone pigments produced by $R$. sphaeroides (PnSB), and the high-resolution calibrated HSI-TChl and HSI-Bphe concentrations. Top: indication of lithogenic flux and general evolution of the chemocline. Bottom: AP / NAP percentages (Kinder et al., 2019; Marcisz et al., 2020) with archeological evidence of human impact and the annual mean temperature variability (Heikkilä and Seppä, 2010).

ity, precipitation and windiness play an important role in lake circulation and are not reflected in the annual mean temperature variability. Hence, the role of climate may be underestimated. The oxic-anoxic stratification was enhanced in this period, but permanent perennial anoxia was still not established as indicated also by the low HSI-Bphe concentrations. The increase in PSB abundance suggests a shallower oxicanoxic boundary (Itoh et al., 2003). It appears that during most of the Holocene, anoxia was largely influenced by primary production and lithogenic flux. The case of Lake Jaczno is different from, e.g., Lake Łazduny (Masurian Lake district, NE Poland; Sanchini et al., 2020), where erosional input is negligible and anoxia was mainly a function of primary production and forest cover.

\subsubsection{Eutrophication, shallow oxic-anoxic boundary and meromixis in the 20th century}

In the period from $500 \mathrm{cal}$ BP to the present, which corresponds to pigment zone I, the phototrophic sulfur bacteria composition changed to an almost complete dominance of purple bacteria (Fig. 6). Between 500-200 cal BP, HSI Bphe and the absolute concentrations of PSB (okenone) and PnSB (spheroidene and spheroidenone) are at a minimum but dominate the phototrophic bacteria community since GSB are 
completely absent (Figs. 4, 6). Lake production (HSI TChl) also decreases while lithogenic flux increases (Fig. 6). This suggests an oxic rather than anoxic phase during this period, with some intervals of weak euxinia. Increased Mn accumulation during this time (Fig. 3) supports the indications of rather oxygenated bottom waters.

Between $200 \mathrm{cal} \mathrm{BP}$ and the present, when human impact started to increase in the catchment (Fig. 5), PSB increased as well. The presence of spheroidene and only trace concentrations of spheroidenone (PnSB) and isorenieratene (GSB) suggest increasing and gradually persisting anoxia. Intensive agriculture in the last 100 years and the use of fertilizers, combined with exceptionally warm summers after $1990 \mathrm{CE}$ (Czernecki and Miętus, 2017; IMGW-PIB, 2017), increased primary production (HSI $T \mathrm{Chl}$ ) substantially to unprecedented levels in the 1990s, relative to the Holocene baseline. This is also reflected in the individual pigment stratigraphy (Fig. 4). Bphe reaches maximum levels, suggesting persisting anoxia and mostly meromictic conditions in the lake, especially since the 1970s when gradual afforestation in the catchment has been observed. This is also supported by the HPLC-inferred composition of phototrophic bacteria (Fig. 3).

In this period, the high-resolution HSI-Bphe record indicates that the intervals of lowest AP in the catchment coincide with absence of Bphe, indicating oxic bottom waters. Bphe increases again only when AP and the tree canopy recovers (Fig. 6), with a parallel absence of spheroidenone (PnSB), suggesting meromictic conditions. Butz et al. (2016, 2017) showed that these intervals of low AP and low or absent Bphe in the sediments were accompanied by strong pulses of terrigenous material from the catchment. The role of human impact with regard to anoxia and interrelated catchment processes (deforestation or afforestation and nutrient inputs) has also been shown in other lakes with diverse timing of human impact onset, for example, Moossee (Makri et al., 2020) and Soppensee (Lotter, 1999) on the Swiss Plateau, lakes Albano and Nemi in Italy (Guilizzoni et al., 2002), and Límni Zazarí in Greece (Gassner et al., 2020) with an early Mid-Holocene human impact and Lake Szurpiły (Kinder et al., 2019) in the vicinity of Lake Jaczno with a late human impact, mainly in the last 500 years.

\section{Conclusions}

In this study, we used a multiproxy approach, combining high-resolution HSI pigment data with lower-resolution HPLC-inferred concentrations of specific algal pigments and geochemical data to investigate algal community composition and its relationship with aquatic production and water column oxygenation in a 9500-year sediment record from NE Poland. Land use changes, vegetation cover and climate variability were also taken into account. Our aim was to examine factors that determine trophic state changes and lake stratifi- cation, in a lake system with stable catchment vegetation and low human impact until very recent times.

The Holocene sedimentary pigment and geochemical record of Lake Jaczno revealed distinct changes in lake trophy and stratification states, mainly driven by the catchment evolution, lithogenic flux, nutrient input and subsequent increase in primary production. The lake had a first phase (9500-6700 cal BP) of low production that consisted mainly of brown algae in the oxic zone but an early immediate establishment of weak euxinic conditions in a deep water column dominated by GSB in its anoxic zone. Increased suspended loads, turbidity currents and underflows seem to have increased turbidity and restricted the proliferation of PSB at the deep oxic-anoxic boundary. Between 6700-500 cal BP, primary production increased gradually with higher contributions of green algae and cyanobacteria, following lake ontogeny in a continuously densely forested catchment. The oxic-anoxic boundary became gradually shallower with a shift from GSB to PSB. The composition of phototrophic bacteria and the presence of spheroidene and spheroidenone $(\mathrm{PnSB})$ in the sediments suggest pronounced yet intermittent euxinia in the lake. Between $500 \mathrm{cal}$ BP and the present, lake trophy increased dramatically, especially in the last 100 years, due to intensified human impact. Eutrophication accompanied by catchment deforestation and subsequent afforestation after land abandonment comprised the main driving forces for the establishment of permanently anoxic and meromictic conditions in the modern lake.

This study highlights the great potential of calibrated and validated HSI measurements combined with HPLC data. Lake Jaczno provided a rare site to explore the mechanisms that can potentially induce changes in lake mixing, lake production and persisting bottom-water anoxia in times from minimum to intensive human impact in a naturally stratified lake system. Our findings, together with findings from other lakes across Europe, can greatly expand our understanding of these major environmental problems while providing a tailored toolset for implementing effective remediation techniques in the future.

Code and data availability. The software code is available in BORIS (https://boris.unibe.ch/id/eprint/149822, Makri et al., 2021).

Supplement. The supplement related to this article is available online at: https://doi.org/10.5194/bg-18-1839-2021-supplement.

Author contributions. SM contributed to investigation and was responsible for data curation, formal analysis, writing of the original draft, and visualization. AL and LT contributed to investigation and the review and editing of the paper. WT and HV contributed to the review and editing of the paper. MG was responsible for concep- 
tualization, methodology, supervision, and funding acquisition and contributed to the review and editing of the paper.

Competing interests. The authors declare that they have no conflict of interest.

Acknowledgements. This study was funded by the Hans-SigristStiftung and Swiss National Science Foundation grants (SNF 200021_172586). We thank Andre F. Lotter, Willi Tanner, Paul Zander and Maurycy Żarczyński for their help during fieldwork. We thank Petra Boltshauser-Kaltenrieder for plant macrofossils identification. Further, we acknowledge Daniela Fischer and Patrick Neuhaus for their assistance in the lab.

Financial support. This research has been supported by the Schweizerischer Nationalfonds zur Förderung der Wissenschaftlichen Forschung (grant no. SNF 200021_172586).

Review statement. This paper was edited by Tom J. Battin and reviewed by two anonymous referees.

\section{References}

Adrian, R., O’Reilly, C. M., Zagarese, H., Baines, S. B., Hessen, D. O., Keller, W., Livingstone, D. M., Sommaruga, R., Straile, D., Van Donk, E., Weyhenmeyer, G. A., and Winder, M.: Lakes as sentinels of climate change, Limnol. Oceanogr., 54, 2283-2297, https://doi.org/10.4319/lo.2009.54.6_part_2.2283, 2009.

Amann, B., Lobsiger, S., Fischer, D., Tylmann, W., Bonk, A., Filipiak, J., and Grosjean, M.: Spring temperature variability and eutrophication history inferred from sedimentary pigments in the varved sediments of Lake Zabińskie, north-eastern Poland, AD 1907-2008, Glob. Planet. Change, 123, 86-96, https://doi.org/10.1016/j.gloplacha.2014.10.008, 2014.

Antoniades, D., Veillette, J., Martineau, M. J., Belzile, C., Tomkins, J., Pienitz, R., Lamoureux, S., and Vincent, W. F.: Bacterial dominance of phototrophic communities in a High Arctic lake and its implications for paleoclimate analysis, Polar Sci., 3, 147-161, https://doi.org/10.1016/j.polar.2009.05.002, 2009.

Bajard, M., Poulenard, J., Sabatier, P., Develle, A. L., GiguetCovex, C., Jacob, J., Crouzet, C., David, F., Pignol, C., and Arnaud, F.: Progressive and regressive soil evolution phases in the Anthropocene, Catena, 150, 39-52, https://doi.org/10.1016/j.catena.2016.11.001, 2017.

Battarbee, R. W. and Bennion, H.: Using palaeolimnological and limnological data to reconstruct the recent history of European lake ecosystems: introduction, Freshw. Biol., 57, 1979-1985, https://doi.org/10.1111/j.1365-2427.2012.02857.x, 2012.

Bennion, H. and Simpson, G. L.: The use of diatom records to establish reference conditions for UK lakes subject to eutrophication, J. Paleolimnol., 45, 469-488, https://doi.org/10.1007/s10933010-9422-8, 2011.
Bianchi, T. S. and Findlay, S.: Decomposition of Hudson estuary macrophytes: Photosynthetic pigment transformations and decay constants, Estuaries, 14, 65-73, https://doi.org/10.2307/1351983, 1991.

Biebl, H. and Pfennig, N.: Growth yields of green sulfur bacteria in mixed cultures with sulfur and sulfate reducing bacteria, Arch. Microbiol., 117, 9-16, https://doi.org/10.1007/BF00689344, 1978.

Bird, D. F. and Kalff, J.: Bacterial Grazing by Planktonic Lake Algae, Science, 231, 493-495, https://doi.org/10.1126/science.231.4737.493, 1986.

Blaauw, M. and Christen, J. A.: Flexible paleoclimate age-depth models using an autoregressive gamma process, Bayesian Anal., 6, 457-474, https://doi.org/10.1214/11-BA618, 2011.

Blaauw, M., Christen, J. A., A. Aquino L., M., Esquivel Vazquez, J., Gonzalez V., O. M., Belding, T., Theiler, J., Gough, B., and Karney, C.: Age-Depth Modelling using Bayesian Statistics, available at: https://CRAN.R-project.org/package=rbacon, last access: 7 May 2020.

Borcard, D., Gillet, F., Legendre, P., Borcard, D., Gillet, F., and Legendre, P.: Canonical Ordination, in Numerical Ecology with R, Springer, New York, NY, 153-225, 2011.

Brown, S. R., McIntosh, H. J., and Smol, J. P.: Recent paleolimnology of a meromictic lake: Fossil pigments of photosynthetic bacteria, SIL Proceedings, 1922-2010, 22, 1357-1360, https://doi.org/10.1080/03680770.1983.11897499, 1984.

Butz, C., Grosjean, M., Fischer, D., Wunderle, S., Tylmann, W., and Rein, B.: Hyperspectral imaging spectroscopy: a promising method for the biogeochemical analysis of lake sediments, J. Appl. Remote Sens., 9, 096031, https://doi.org/10.1117/1.JRS.9.096031, 2015.

Butz, C., Grosjean, M., Poraj-Górska, A., Enters, D., and Tylmann, W.: Sedimentary Bacteriopheophytin a as an indicator of meromixis in varved lake sediments of Lake Jaczno, north-east Poland, CE 1891-2010, Glob. Planet. Change, 144, 109-118, https://doi.org/10.1016/j.gloplacha.2016.07.012, 2016.

Butz, C., Grosjean, M., Goslar, T., and Tylmann, W.: Hyperspectral imaging of sedimentary bacterial pigments: a 1700-year history of meromixis from varved Lake Jaczno, northeast Poland, J. Paleolimnol., 58, 57-72, https://doi.org/10.1007/s10933-017-9955$1,2017$.

Cartaxana, P., Jesus, B., and Brotas, V.: Pheophorbide and pheophytin a-like pigments as useful markers for intertidal microphytobenthos grazing by Hydrobia ulvae, Estuar. Coast. Shelf Sci., 58, 293-297, https://doi.org/10.1016/S0272-7714(03)00081-7, 2003.

Costa, K. M., Russell, J. M., Vogel, H., and Bijaksana, S.: Hydrological connectivity and mixing of Lake Towuti, Indonesia in response to paleoclimatic changes over the last 60,000 years, Palaeogeogr. Palaeocl., 417, 467-475, https://doi.org/10.1016/j.palaeo.2014.10.009, 2015.

Croudace, I. W. and Rothwell, R. G.: Future Developments and Innovations in High-Resolution Core Scanning, in: Micro-XRF Studies of Sediment Cores, Developments in Paleoenvironmental Research, edited by: Croudace, I. and Rothwell, R., Springer, Dordrecht, 627-647, 2015.

Czernecki, B. and Miętus, M.: The thermal seasons variability in Poland, 1951-2010, Theor. Appl. Climatol., 127, 481-493, https://doi.org/10.1007/s00704-015-1647-z, 2017. 
Diaz, R. and Rosenberg, R.: Spreading Dead Zones and Consequences for Marine Ecosystems, Science, 321, 926-929, https://doi.org/10.1126/science.1156401, 2008.

Engel, M. and Sobczak, C.: Nie tylko archeologia. Interdyscyplinarne badania wielokulturowego zespołu osadniczego w Szurpiłach na Suwalszczyźnie, Pruthenia, 7, 137-157, 2012.

Enters, D., Kirilova, E., Lotter, A. F., Lücke, A., Parplies, J., Jahns, S., Kuhn, G., and Zolitschka, B.: Climate change and human impact at Sacrower See (NE Germany) during the past 13,000 years: A geochemical record, J. Paleolimnol., 43, 719737, https://doi.org/10.1007/s10933-009-9362-3, 2010.

Fiedor, J., Fiedor, L., Kammhuber, N., Scherz, A., and Scheer, H.: Photodynamics of the bacterlochlorophyll-carotenoid system, 2. Influence of central metal, solvent and beta-carotene on photobleaching of bacteriochlorophyll derivatives, Photochem. Photobiol., 76, 145-152, https://doi.org/10.1562/00318655(2002)076<0145:potbcs>2.0.co;2, 2002.

Friedrich, J., Janssen, F., Aleynik, D., Bange, H. W., Boltacheva, N., Çagatay, M. N., Dale, A. W., Etiope, G., Erdem, Z., Geraga, M., Gilli, A., Gomoiu, M. T., Hall, P. O. J. J., Hansson, D., He, Y., Holtappels, M., Kirf, M. K., Kononets, M., Konovalov, S., Lichtschlag, A., Livingstone, D. M., Marinaro, G., Mazlumyan, S., Naeher, S., North, R. P., Papatheodorou, G., Pfannkuche, O., Prien, R., Rehder, G., Schubert, C. J., Soltwedel, T., Sommer, S., Stahl, H., Stanev, E. V., Teaca, A., Tengberg, A., Waldmann, C., Wehrli, B., and Wenzhöfer, F.: Investigating hypoxia in aquatic environments: Diverse approaches to addressing a complex phenomenon, Biogeosciences, 11, 1215-1259, https://doi.org/10.5194/bg-11-1215-2014, 2014.

Gächter, R.: Lake restoration. Why oxygenation and artificial mixing cannot substitute for a decrease in the external phosphorus loading, Swiss J. Hydrol., 49, 170-185, https://doi.org/10.1007/BF02538501, 1987.

Gałka, M.: Pattern of plant succession from eutrophic lake to ombrotrophic bog in NE Poland over the last 9400 years based on high-resolution macrofossil analysis, Ann. Bot. Fenn., 51, 1-21, https://doi.org/10.5735/085.051.0101, 2014.

Gassner, S., Gobet, E., Schwörer, C., van Leeuwen, J., Vogel, H., Giagkoulis, T., Makri, S., Grosjean, M., Panajiotidis, S., Hafner, A., and Tinner, W.: 20,000 years of interactions between climate, vegetation and land use in Northern Greece, Veg. Hist. Archaeobot., 29, 75-90, https://doi.org/10.1007/s00334019-00734-5, 2020.

Guilizzoni, P. and Lami, A.: Paleolimnology: Use of Algal Pigments as Indicators, in: Encyclopedia of Environmental Microbiology, edited by: Bitton, G., John Wiley \& Sons, Inc., 2306-2317, 2002.

Guilizzoni, P., Bonomi, G., Galanti, G., and Ruggiu, D.: Paleolimnology: Relationship between sedimentary pigments and primary production: evidence from core analyses of twelve Italian lakes, in: Hydrobiologia, Vol. 103, edited by: Meriläinen, J., Huttunen, P., and Battarbee, R. W., Kluwer Academic Publishers, The Hague, the Netherlands, 103-106, 1983.

Guilizzoni, P., Lami, A., Marchetto, A., Jones, V., Manca, M., and Bettinetti, R.: Palaeoproductivity and environmental changes during the Holocene in central Italy as recorded in two crater lakes (Albano and Nemi), Quaternary Int., 88, 57-68, https://doi.org/10.1016/S1040-6182(01)00073-8, 2002.

Heikkilä, M. and Seppä, H.: Holocene climate dynamics in Latvia, eastern Baltic region: A pollen-based summer temperature re- construction and regional comparison, Boreas, 39, 705-719, https://doi.org/10.1111/j.1502-3885.2010.00164.x, 2010.

Heiri, O., Lotter, A. F., and Lemcke, G.: Loss on ignition as a method for estimating organic and carbonate content in sediments: reproducibility and comparability of results, J. Paleolimnol., 25, 101-110, 2001.

Howarth, R. W., Chan, F., and Marino, R.: Do top-down and bottom-up controls interact to exclude nitrogen-fixing cyanobacteria from the plankton of estuaries? An exploration with a simulation model, Biogeochemistry, 46, 203-231, https://doi.org/10.1007/BF01007580, 1999.

Hubas, C., Jesus, B., Passarelli, C., and Jeanthon, C.: Tools providing new insight into coastal anoxygenic purple bacterial mats: Review and perspectives, Res. Microbiol., 162, 858-868, https://doi.org/10.1016/j.resmic.2011.03.010, 2011.

Hubas, C., Jesus, B., Ruivo, M., Meziane, T., Thiney, N., Davoult, D., Spilmont, N., Paterson, D. M., and Jeanthon, C.: Proliferation of purple sulphur bacteria at the sediment surface affects intertidal mat diversity and functionality, PLoS One, 8, 1-13, https://doi.org/10.1371/journal.pone.0082329, 2013.

Hurley, J. P.: Analysis of aquatic pigments by high performance liquid chromatography, J. Anal. Purif., 3, 12-16, 1988.

IMGW-PIB: Suwałki Meteorological Station, Inst. Meteorol. Water Manag., available at: https://danepubliczne.imgw.pl/ \#wprowadzenie (last access: 8 July 2020), 2017.

Imhoff, J. F.: Biology of Green Sulfur Bacteria, in: eLS, John Wiley \& Sons, Ltd, Chichester, https://doi.org/10.1002/9780470015902.a0000458.pub2, 2014.

Itoh, N., Tani, Y., Nagatani, T., and Soma, M.: Phototrophic activity and redox condition in Lake Hamana, Japan, indicated by sedimentary photosynthetic pigments and molybdenum over the last $\sim 250$ years, J. Paleolimnol., 29, 403-422, https://doi.org/10.1023/A:1024407210928, 2003.

Jeffrey, S., Wright, S., and Zapata, M.: Microalgal classes and their signature pigments, Phytoplankton pigments, Characterization, Chemotaxonomy, and Applications in Oceanography, edited by: Roy, S., Llewellyn, C. A., Egeland, E. S., and Johnsen, G., Cambridge University Press, Cambridge, UK, 1-77, 2011.

Jeffrey, S. W. and Humphrey, G. F.: New spectrophotometric equations for determining chlorophylls $a, b, c 1$ and $c 2$ in higher plants, algae and natural phytoplankton, Biochem. Physiol.Pflanz., 167, 191-194, https://doi.org/10.1016/S00153796(17)30778-3, 1975.

Jenny, J.-P., Francus, P., Normandeau, A., Lapointe, F., Perga, M. E., Ojala, A., Schimmelmann, A., and Zolitschka, B.: Global spread of hypoxia in freshwater ecosystems during the last three centuries is caused by rising local human pressure, Glob. Change Biol., 22, 1481-1489, https://doi.org/10.1111/gcb.13193, 2016a.

Jenny, J.-P., Normandeau, A., Francus, P., Taranu, Z. E., GregoryEaves, I., Lapointe, F., Jautzy, J., Ojala, A. E. K., Dorioz, J.M., Schimmelmann, A., and Zolitschka, B.: Urban point sources of nutrients were the leading cause for the historical spread of hypoxia across European lakes, P. Natl. Acad. Sci. USA, 113, 12655-12660, https://doi.org/10.1073/pnas.1605480113, 2016b.

Kinder, M., Tylmann, W., Bubak, I., Fiłoc, M., Gąsiorowski, M., Kupryjanowicz, M., Mayr, C., Sauer, L., Voellering, U., and Zolitschka, B.: Holocene history of human impacts inferred from annually laminated sediments in Lake Szurpiły, northeast Poland, 
J. Paleolimnol., 61, 419-435, https://doi.org/10.1007/s10933019-00068-2, 2019.

Kinder, M., Tylmann, W., Rzeszewski, M., and Zolitschka, B.: Varves and mass-movement deposits record distinctly different sedimentation dynamics since the late glacial (Lake Szurpiły, northeastern Poland), Quaternary Res., 93, 299-313, https://doi.org/10.1017/qua.2019.61, 2020.

Koinig, K. A., Shotyk, W., Lotter, A. F., Ohlendorf, C., and Sturm, M.: 9000 years of geochemical evolution of lithogenic major and trace elements in the sediment of an alpine lake - the role of climate, vegetation, and land-use history, J. Paleolimnol., 30, 307320, 2003.

Kosourov, S., Murukesan, G., Jokela, J., and Allahverdiyeva, Y.: Carotenoid biosynthesis in calothrix sp. 336/3: Composition of carotenoids on full medium, during diazotrophic growth and after long-term H2 photoproduction, Plant Cell Physiol., 57, 22692282, https://doi.org/10.1093/pcp/pcw143, 2016.

Krzywicki, T.: The maximum ice sheet limit of the Vistulian Glaciation in northeastern Poland and neighbouring areas, Geol. Q., 46, 165-188, 2002.

Lami, A., Niessen, F., Guilizzoni, P., Masaferro, J., and Belis, C. A.: Palaeolimnological studies of the eutrophication of volcanic Lake Albano (Central Italy), J. Paleolimnol., 10, 181-197, 1994.

Lami, A., Guilizzoni, P., and Marchetto, A.: High resolution analysis of fossil pigments, carbon, nitrogen and sulphur in the sediment of eight European Alpine lakes: the MOLAR project, edited by: Lami, A., Cameron, N., and Korhola, A., J. Limnol., 59, 1528, 2000.

Leavitt, P. R.: A review of factors that regulate carotenoid and chlorophyll deposition and fossil pigment abundance, J. Paleolimnol., 9, 109-127, 1993.

Leavitt, P. R. and Hodgson, D.: Sedimentary Pigments, in Tracking Environmental Change Using Lake Sediments, Vol. 3, edited by: Smol, J., Birks, H., and Last, W., Kluwer, Dordrecht, 295-325, 2001.

Legendre, P. and Legendre, L.: Numerical ecology, 2nd Edn., Amsterdam, 575-635, 1998.

Little, J. L., Quinlan, R., Smol, J. P., and Hall, R. I.: Past trophic status and hypolimnetic anoxia during eutrophication and remediation of Gravenhurst Bay, Ontario: Comparison of diatoms, chironomids, and historical records, Can. J. Fish. Aquat. Sci., 57, 333-341, https://doi.org/10.1139/f99-235, 2000.

Lotter, A. F.: Late-glacial and Holocene vegetation history and dynamics as shown by pollen and plant macrofossil analyses in annually laminated sediments from Soppensee, central Switzerland, Veg. Hist. Archaeobot., 8, 165-184, https://doi.org/10.1007/BF02342718, 1999.

Lürling, M., Mello, M. M., van Oosterhout, F., de Domis, L. S., and Marinho, M. M.: Response of natural cyanobacteria and algae assemblages to a nutrient pulse and elevated temperature, Front. Microbiol., 9, p. 1851, https://doi.org/10.3389/fmicb.2018.01851, 2018.

Madigan, M. T. and Jung, D. O.: An Overview of Purple Bacteria: Systematics, Physiology, and Habitats, in: The Purple Phototrophic Bacteria. Advances in Photosynthesis and Respiration, edited by: Hunter, C. N., Daldal, F., Thurnauer, M. C., and Beatty, J. T., Springer, Dordrecht, 1-15, 2009.

Makri, S., Lami, A., Lods-Crozet, B., and Loizeau, J.-L.: Reconstruction of trophic state shifts over the past 90 years in a eu- trophicated lake in western Switzerland, inferred from the sedimentary record of photosynthetic pigments, J. Paleolimnol., 61, 129-145, https://doi.org/10.1007/s10933-018-0049-5, 2019.

Makri, S., Rey, F., Gobet, E., Gilli, A., Tinner, W., and Grosjean, M.: Early human impact in a 15,000-year high-resolution hyperspectral imaging record of paleoproduction and anoxia from a varved lake in Switzerland, Quaternary Sci. Rev., 239, 106335, https://doi.org/10.1016/j.quascirev.2020.106335, 2020.

Makri, S., Lami, A., Tu, L., Tylmann, W., Vogel, H., and Grosjean, M.: Holocene phototrophic community and anoxia dynamics in meromictic Lake Jaczno (NE Poland) using high-resolution hyperspectral imaging and HPLC data, Dataset, available at: https:// boris.unibe.ch/id/eprint/149822 (last access: 22 February 2021), https://doi.org/10.7892/boris.149822, 2021.

Manske, A. K., Glaeser, J., Kuypers, M. M. M., and Overmann, J.: Physiology and phylogeny of green sulfur bacteria forming a monospecific phototrophic assemblage at a depth of 100 meters in the black sea, Appl. Environ. Microbiol., 71, 8049-8060, https://doi.org/10.1128/AEM.71.12.8049-8060.2005, 2005.

Mantoura, R. F. C. and Llewellyn, C. A.: The rapid determination of algal chlorophyll and carotenoid pigments and their breakdown products in natural waters by reverse-phase high-performance liquid chromatography, Anal. Chim. Acta, 151, 297-314, 1983.

Marcisz, K., Kołaczek, P., Gałka, M., Diaconu, A.-C., and Lamentowicz, M.: Exceptional hydrological stability of a Sphagnumdominated peatland over the late Holocene, Quaternary Sci. Rev., 231, 106180, https://doi.org/10.1016/j.quascirev.2020.106180, 2020.

Meyers, P. A.: Applications of organic geochemistry to paleolimnological reconstructions: A summary of examples from the Laurentian Great Lakes, Organ. Geochem., 34, 261-289, 2003.

Montesinos, E., Guerrero, R., Abella, C., and Esteve, I.: Ecology and Physiology of the Competition for Light Between Chlorobium limicola and Chlorobium phaeobacteroides in Natural Habitats, Appl. Environ. Microbiol., 46, 1007-1016, https://doi.org/10.1128/aem.46.5.1007-1016.1983, 1983.

Munsell Color (Firm): Munsell soil color charts: with genuine Munsell color chips, 2009 year revised. Grand Rapids, MI: Munsell Color, 2010.

Murtagh, F. and Legendre, P.: Ward's Hierarchical Agglomerative Clustering Method: Which Algorithms Implement Ward's Criterion?, J. Classif., 31, 274-295, https://doi.org/10.1007/s00357014-9161-z, 2014.

Naeher, S., Smittenberg, R. H., Gilli, A., Kirilova, E. P., Lotter, A. F., and Schubert, C. J.: Impact of recent lake eutrophication on microbial community changes as revealed by high resolution lipid biomarkers in Rotsee (Switzerland), Org. Geochem., 49, 86-95, https://doi.org/10.1016/j.orggeochem.2012.05.014, 2012.

Naeher, S., Gilli, A., North, R. P., Hamann, Y., and Schubert, C. J.: Tracing bottom water oxygenation with sedimentary $\mathrm{Mn} / \mathrm{Fe}$ ratios in Lake Zurich, Switzerland, Chem. Geol., 352, 125-133, https://doi.org/10.1016/j.chemgeo.2013.06.006, 2013.

Oksanen, J., Kindt, R., Pierre, L., O’Hara, B., Simpson, G. L., Solymos, P., Stevens, M. H. . H. H., Wagner, H., Blanchet, F. G., Kindt, R., Legendre, P., Minchin, P. R., O’Hara, R. B., Simpson, G. L., Solymos, P., Stevens, M. H. . H. H., and Wagner, H.: vegan: Community Ecology Package, R package version 2.4-0, R Packag. version 2.2-1, available at: http://vegan.r-forge.r-project. org, 2016. 
Oren, A.: 12 - Characterization of Pigments of Prokaryotes and Their Use in Taxonomy and Classification, in Taxonomy of Prokaryotes, vol. 38, edited by F. Rainey and A. B. T.-M. in M. Oren, pp. 261-282, Academic Press., 2011.

Parkin, T. B. and Brock, T. D.: Photosynthetic bacterial production in lakes: The effects of light intensity, Limnol. Oceanogr., 25, 711-718, https://doi.org/10.4319/lo.1980.25.4.0711, 1980.

Pearson, F. J. and Coplen, T. B.: Stable Isotope Studies of Lakes, in: Lakes, edited by: Lerman, A. Springer, New York, NY, 325-339, 1978.

Poraj-Górska, A. I., Żarczyński, M. J., Ahrens, A., Enters, D., Weisbrodt, D., and Tylmann, W.: Impact of historical land use changes on lacustrine sedimentation recorded in varved sediments of Lake Jaczno, northeastern Poland, Catena, 153, 182193, https://doi.org/10.1016/j.catena.2017.02.007, 2017.

R Core Team: R: A language and environment for statistical computing, available at: http://www.r-project.org, 2015.

Reimer, P. J., Bard, E., Bayliss, A., Beck, J. W., Blackwell, P. G., Ramsey, C. B., Buck, C. E., Cheng, H., Edwards, R. L., Friedrich, M., Grootes, P. M., Guilderson, T. P., Haflidason, H., Hajdas, I., Hatté, C., Heaton, T. J., Hoffmann, D. L., Hogg, A. G., Hughen, K. A., Kaiser, K. F., Kromer, B., Manning, S. W., Niu, M., Reimer, R. W., Richards, D. A., Scott, E. M., Southon, J. R., Staff, R. A., Turney, C. S. M., and van der Plicht, J.: IntCal13 and Marine13 Radiocarbon Age Calibration Curves 0-50,000 Years cal BP, Radiocarbon, 55, 1869-1887, https://doi.org/10.2458/azu_js_rc.55.16947, 2013.

Sanchini, A., Szidat, S., Tylmann, W., Vogel, H., Wacnik, A., and Grosjean, M.: A Holocene high-resolution record of aquatic productivity, seasonal anoxia and meromixis from varved sediments of Lakełazduny, North-Eastern Poland: insight from a novel multi-proxy approach, J. Quaternary Sci., 35, 1070-1080, https://doi.org/10.1002/jqs.3242, 2020.

Schindler, D. W.: Recent advances in the understanding and management of eutrophication, Limnol. Oceanogr., 51, 356-363, https://doi.org/10.4319/lo.2006.51.1_part_2.0356, 2006.

Schneider, T., Rimer, D., Butz, C., and Grosjean, M.: A highresolution pigment and productivity record from the varved Ponte Tresa basin (Lake Lugano, Switzerland) since 1919: insight from an approach that combines hyperspectral imaging and high-performance liquid chromatography, J. Paleolimnol., 60, 381-398, https://doi.org/10.1007/s10933-018-0028-x, 2018.

Schnurrenberger, D., Russell, J., and Kelts, K.: Classification of lacustrine sediments based on sedimentary components, J. Paleolimnol., 29, 141-154, https://doi.org/10.1023/A:1023270324800, 2003.

Smith, V. H. and Schindler, D. W.: Eutrophication science: where do we go from here?, Trends Ecol. Evol., 24, 201-207, https://doi.org/10.1016/j.tree.2008.11.009, 2009.

Smol, J. P.: The power of the past: using sediments to track the effects of multiple stressors on lake ecosystems, Freshw. Biol., 55, 43-59, https://doi.org/10.1111/j.1365-2427.2009.02373.x, 2010.

Stuiver, M. and Reimer, P. J.: Extended ${ }^{14} \mathrm{C}$ data base and revised CALIB $3.0{ }^{14} \mathrm{C}$ age calibration program, Radiocarbon, 35, 215230, https://doi.org/10.1017/S0033822200013904, 1993.

Szidat, S., Salazar, G. A., Vogel, E., Battaglia, M., Wacker, L., Synal, H.-A., and Türler, A.: 14C Analysis and Sample Preparation at the New Bern Laboratory for the Analysis of
Radiocarbon with AMS (LARA), Radiocarbon, 56, 561-566, https://doi.org/10.1017/s0033822200049602, 2014.

Tõnno, I., Nauts, K., Belle, S., Nõmm, M., Freiberg, R., Kõiv, T., and Alliksaar, T.: Holocene shifts in the primary producer community of large, shallow European Lake Peipsi, inferred from sediment pigment analysis, J. Paleolimnol., 61, 403-417, https://doi.org/10.1007/s10933-019-00067-3, 2019.

Tu, L., Jarosch, K. A., Schneider, T., and Grosjean, M.: Phosphorus fractions in sediments and their relevance for historical lake eutrophication in the Ponte Tresa basin (Lake Lugano, Switzerland) since 1959, Sci. Total Environ., 685, 806-817, https://doi.org/10.1016/j.scitotenv.2019.06.243, 2019.

Tylmann, W., Zolitschka, B., Enters, D., and Ohlendorf, C.: Laminated lake sediments in northeast Poland: Distribution, preconditions for formation and potential for paleoenvironmental investigation, J. Paleolimnol., 50, 487-503, https://doi.org/10.1007/s10933-013-9741-7, 2013.

Vitousek, P. M., Cassman, K., Cleveland, C., Crews, T., Field, C. B., Grimm, N. B., Howarth, R. W., Marino, R., Martinelli, L., Rastetter, E. B., and Sprent, J. I.: Towards an ecological understanding of biological nitrogen fixation, Biogeochemistry, 57/58, $1-45,2002$.

Weisbrodt, D., Enters, D., Żarczyński, M. J., Poraj-Górska, A. I., and Tylmann, W.: Contribution of non-pollen palynomorphs to reconstructions of land-use changes and lake eutrophication: case study from Lake Jaczno, northeastern Poland, Limnol. Rev., 16, 247-256, https://doi.org/10.1515/limre-2016-0027, 2017.

Wetzel, R. G.: Limnology: Lake and River Ecosystems, 3rd Edn., Acedemic Press, USA, 331-393, 2001.

Wirth, S. B., Gilli, A., Niemann, H., Dahl, T. W., Ravasi, D., Sax, N., Hamann, Y., Peduzzi, R., Peduzzi, S., Tonolla, M., Lehmann, M. F., and Anselmetti, F. S.: Combining sedimentological, trace metal (Mn, Mo) and molecular evidence for reconstructing past water-column redox conditions: The example of meromictic Lake Cadagno (Swiss Alps), Geochim. Cosmochim. Acta, 120, 220-238, https://doi.org/10.1016/j.gca.2013.06.017, 2013.

Woolway, R. I. and Merchant, C. J.: Worldwide alteration of lake mixing regimes in response to climate change, Nat. Geosci., 12, 271-276, https://doi.org/10.1038/s41561-019-0322-x, 2019.

Yurkov, V. V and Beatty, J. T.: Aerobic Anoxygenic Phototrophic Bacteria, Microbiol. Mol. Biol. Rev., 62, 695-724, 1998.

Zander, P. D., Szidat, S., Kaufman, D. S., Żarczyński, M., Porajgórska, A. I., and Grosjean, M.: Miniature radiocarbon measurements $(<150 \mu \mathrm{g} \mathrm{C})$ from sediments of Lake Żabińskie, Poland: effect of precision and dating density on age-depth models, Geochronology, 2, 63-79, https://doi.org/10.5194/gchron-263-2020, 2020.

Zolitschka, B., Francus, P., Ojala, A. E. K., and Schimmelmann, A.: Varves in lake sediments - a review, Quaternary Sci. Rev., 117, 1-41, https://doi.org/10.1016/j.quascirev.2015.03.019, 2015.

Züllig, H.: Untersuchungen über die Stratigraphie von Carotinoiden im geschichteten Sediment von 10 Schweizer Seen zur Erkundung früherer Phytoplankton-Entfaltungen, Schweiz. Zeit. Hydrol., 44, 1-98, 1982.

Züllig, H.: Role of carotenoids in lake sediments for reconstructing trophic history during the late Quaternary, J. Paleolimnol., 2, 2340, https://doi.org/10.1007/BF00156982, 1989. 